\section{OPEN ACCESS}

Edited by:

François Criscuolo,

Centre National de la Recherche

Scientifique (CNRS), France

Reviewed by:

Michael Kopp,

Aix-Marseille University, France

Bram Kuijper,

University of Exeter, UK

*Correspondence:

K. G. Srikanta Dan

srikantadani@yahoo.co.uk

Specialty section:

This article was submitted to Behavioral and Evolutionary Ecology,

a section of the journal

Frontiers in Ecology and Evolution

Received: 04 September 2016

Accepted: 18 April 2017

Published: 22 May 2017

Citation:

Dani KGS and Kodandaramaiah U (2017) Plant and Animal Reproductive

Strategies: Lessons from Offspring

Size and Number Tradeoffs.

Front. Ecol. Evol. 5:38.

doi: 10.3389/fevo.2017.00038

\title{
Plant and Animal Reproductive Strategies: Lessons from Offspring Size and Number Tradeoffs
}

\section{K. G. Srikanta Dani * and Ullasa Kodandaramaiah}

IISER-TVM Centre for Research and Education in Ecology and Evolution (ICREEE), School of Biology, Indian Institute of Science Education and Research Thiruvananthapuram, Thiruvananthapuram, India

The tradeoff between offspring size and number is ubiquitous and manifestly similar in plants and animals despite fundamental differences between the evolutionary histories of these two major life forms. Fecundity (offspring number) primarily affects parental fitness, while offspring size underpins the fitness of parents and offspring. We provide an overview of theoretical models dealing with offspring size and fitness relationships. We follow that with a detailed examination of life-history constraints and environmental effects on offspring size and number, separately in plants and animals. The emphasis is on seed plants, but we endeavor to also summarize information from distinct animal groups -insects, fishes, reptiles, birds, and mammals. Furthermore, we analyse genetic controls on offspring size and number in two model organisms-Arabidopsis and Drosophila. Despite the deep evolutionary divergence between plants and animals, we find four trends in reproductive strategy that are common to both lineages: (i) offspring size is generally less variable than offspring number, (ii) offspring size increases with increasing parent body size, (iii) maternal genes restrict offspring size and increase offspring numbers, while zygotic genes act to increase offspring size; such parent-offspring conflicts are enhanced when there is sibling rivalry, and (iv) variation in offspring size increases under sub-optimal (harsh) environmental conditions. The most salient difference between plants and animals is that the latter tend to produce larger (fewer) offspring under sub-optimal conditions while seed plants invest in smaller (many) seeds, suggesting that maternal genetic control over offspring size increases in plants but decreases in animals with parental care. The time is ripe for greater experimental exploration of genetic controls on reproductive allocation and parent-offspring conflicts in plants and animals under sub-optimal (harsh) environments.

Keywords: parent-offspring conflicts, offspring size-number tradeoff, sibling rivalry, maternal genetic controls, optimization models, Arabidopsis, life-history evolution 


\section{INTRODUCTION}

One of the most enduring research problems in evolutionary biology is understanding how organisms invest resources into reproduction, and the dynamic selective forces and tradeoffs that bear upon this. In an evolutionary context, a tradeoff incurs a fitness cost when a beneficial change in a trait is coupled with a detrimental change in another (Stearns, 1989). Natural selection has given rise to an incredible diversity of reproductive strategies, yet a tradeoff between offspring size and number (fecundity) is universal (Harper et al., 1970; Fox and Czesak, 2000). A large body of theoretical and empirical work has addressed this tradeoff, but emphasis has been either on plants (by botanists) or on animals (by zoologists); rarely has it been inclusive of both. It is only the rare biologist who studies both plants and animals (e.g., Wallace, 1878; Bradshaw, 1972), and rarer are those who study both systems with an intention to decode ecological and evolutionary tradeoffs (e.g., Darwin, 1859). The fact that work so far has looked at either plants or animals exclusively is understandable given the profound differences in ecological and life-history attributes of the two lineages, which diverged at least 1.5 billion years ago (Wang et al., 1999). Although both plants and animals have diversified tremendously in their reproductive strategies, their fitness is inevitably determined by both quality and quantity of offspring, and is limited by resource availability. Thus, the reproductive strategies of these deeply divergent lineages may have converged due to the underlying similarity in evolutionary pressures and constraints. Indeed, the cardinal theoretical construct for the offspring size-vs.-number tradeoff (Smith and Fretwell, 1974) was mostly agnostic with respect to the two taxonomic groups. Following this seminal paper, there has been a substantial body of work dedicated to understanding variation in offspring size and number, but we still do not fully understand why and how this diversity evolves.

Several studies have established a strong negative correlation between seed size and seed number within and across plants species (Greene and Johnson, 1994; Turnbull et al., 1999; Jakobsson and Eriksson, 2000). In recent decades, a few comprehensive reviews have evaluated the differences in seed size in the context of variation (a) within species (Harper et al., 1970), (b) amongst plant functional groups (Westoby et al., 1992; Coomes and Grubb, 2003), (c) in the productivity of crop plants (Sadras, 2007), (d) in mechanisms of dormancy and germination (Rees, 1996; Finch-Savage and Leubner-Metzger, 2006), and the consequences of these differences for the evolution and diversification of seed plants (Leishman et al., 2000; Moles et al., 2005; Linkies et al., 2010). Similarly, among animals, a negative correlation between offspring size and number (fecundity) is widespread across evolutionary scales-(a) within individuals, (b) among individuals of a population, (c) across populations, and (d) across species and higher-level taxonomic groups-thus there is robust evidence for a tradeoff between offspring size and number (Lawlor, 1976; Berrigan, 1991; Sinervo and Licht, 1991; Roff, 1992; Stearns, 1992; Clarke, 1993; Carrière and Roff, 1995; Mckee and Ebert, 1996; Guntrip et al., 1997; Schwarzkopf et al., 1999; Ernsting and Isaaks, 2000; Fox and Czesak, 2000; García-Barros, 2000a,b; Fischer and Fiedler, 2001; Kolm et al., 2006b).
The quest to explain the changing shapes of the offspring size-vs.-number tradeoff (hereafter size-number tradeoff) within species has led to arguments with mutually exclusive and opposing emphases on the roles played by environmental variation (Janzen, 1969; Kaplan and Cooper, 1984) and genetic/developmental constraints (McGinley et al., 1987). However, strong empirical evidence supporting either argument is scarce. This review revolves around the size-number tradeoff to highlight various unanswered facets of the evolutionary ecology of plant and animal reproductive strategies. We begin by providing an overview of theoretical models of progeny size and fitness relationships, applicable equally to plants and animals. From that point onwards, we develop the discussion on plants and animals separately. After discussing theory, we summarize important life-history constraints on offspring size and number and then explore evidence for parent-offspring conflict at the genetic level in model organisms (Arabidopsis and Drosophila). Finally, we evaluate how the size-number tradeoff is affected by environmental variables. Wherever feasible, we juxtapose available evidence with the predictions of theoretical models.

Reviews focused on animal reproductive strategies already exist (e.g., Fox and Czesak, 2000 for arthropods; Godfray et al., 1991; Monaghan and Nager, 1997 for birds; Einum et al., 2004 for fishes; Bernardo, 1996; Roff, 2002 for animals in general). The animal section aims to distill information from these reviews and from more recent literature, and synthesize the salient points. On the other hand, detailed reviews on plant reproductive strategies are lacking. Therefore, the plant section endeavors to provide a fairly comprehensive review of the literature related to this theme. We aim to exploit commonalities between animals and seed plants to identify broad trends in reproductive strategies of the two lineages. In all of the following, the term "offspring" may refer to seeds in plants, eggs in oviparous animals, and neonates in viviparous animals.

\section{MODELS TACKLING REPRODUCTIVE ECONOMY}

The theoretical underpinnings of the offspring size-number tradeoff have their origins in ornithology. Pioneering work by David Lack in the 1940s on the evolution of clutch size in birds ignited a rich series of studies on vertebrate systems, and later also on invertebrates and plants. Initially, clutch size models for vertebrates and invertebrates were developed independently, both inspired by optimal foraging models (Charnov, 1976; Parker and Stuart, 1976; Stephens et al., 2007), but converged over time (Wilson and Lessells, 1994).

The ground-breaking model by Smith and Fretwell (1974) (hereafter the SF model) assumes that offspring fitness increases with parental investment but experiences diminishing returns (Figure 1A). As a consequence, parental fitness is maximized by an intermediate (optimal) investment in individual offspring. The offspring size corresponding to the maternal parent's optimum $\left(\mathrm{m}^{*}\right)$ is inferred by drawing a tangent through the origin to the SF curve (Smith and Fretwell, 1974). Investing more than $\mathrm{m}^{*}$ in individual offspring decreases parental fitness. In contrast, the offspring benefits by procuring as many resources 

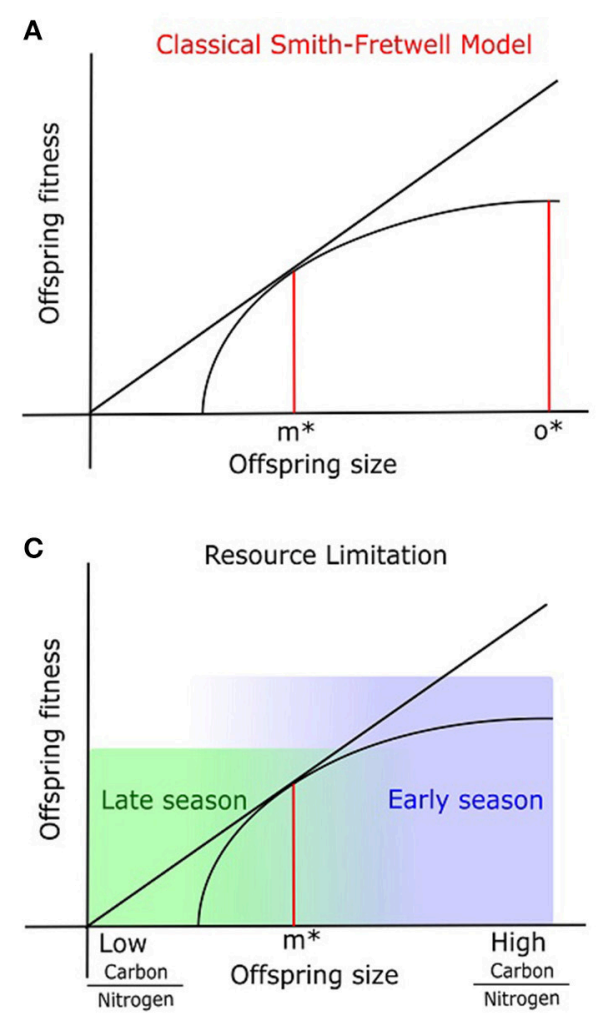

E

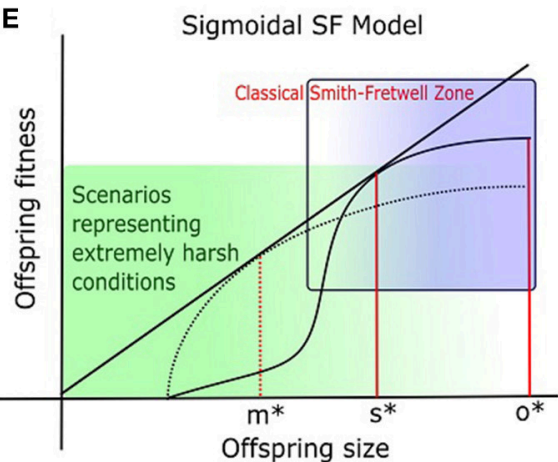

$\mathrm{m}^{*}$ Offspring size for optimal maternal fitness o* Offspring size for maximum offspring fitness $s^{*}$ Offspring size of a superior offspring for optimal maternal fintess

i* Offspring size for an inferior offspring for optimal maternal fitness
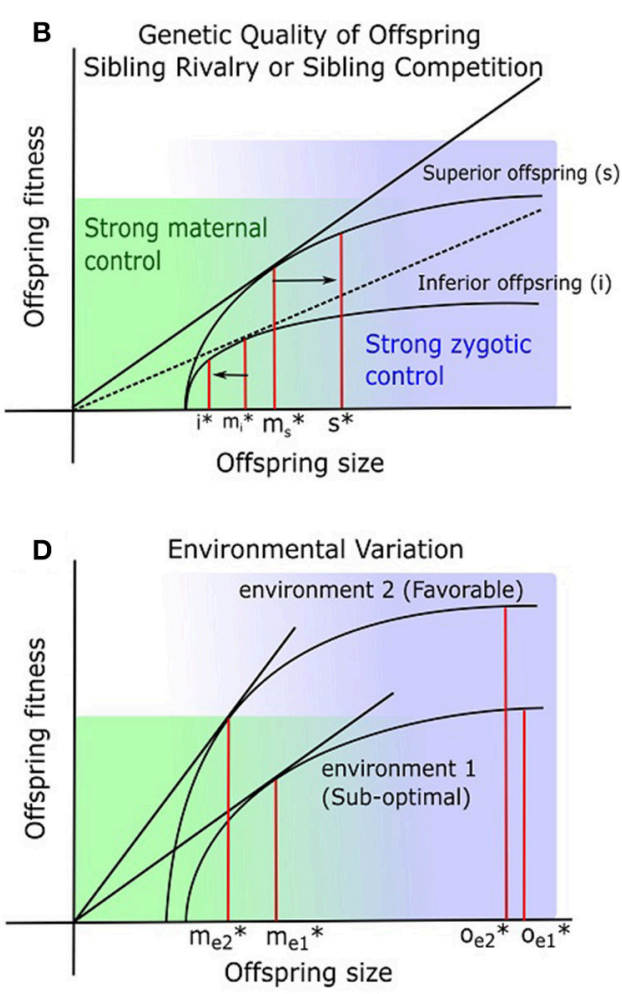

Interaction of Environment and Developmental Constraints

\footnotetext{
$\mathbf{F}$
}

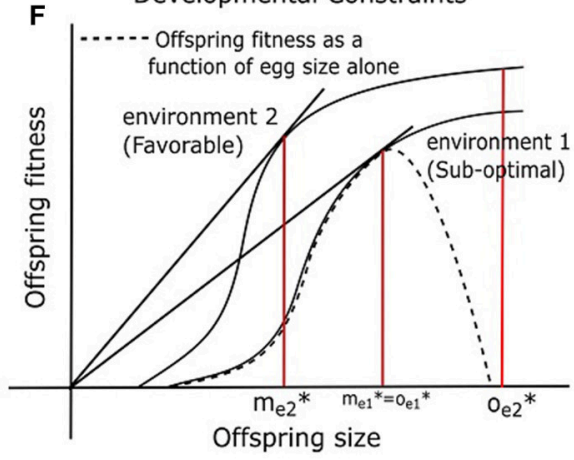

Maternal genetic controls over offspring size

Zygotic genetic controls over offspring size

FIGURE 1 | Optimization models tackling offspring size and fitness (A) Classical Smith and Fretwell model (SF model; Smith and Fretwell, 1974), (B) SF model in the context of genetic quality of offspring and sibling rivalry (see Haig, 1990), (C) SF model in the context of resource limitation (adapted from McGinley and Charnov, 1988), (D) Changing slope of the SF curve in response to changing environmental condition (Einum et al., 2004), (E) More accurate sigmoidal representation of the SF model, placed on top of the classical curve (dotted line), and (F) A special case of (D), where developmental constraints influence offspring fitness (modified from Hendry et al., 2001). The letters symbolize offspring size for maximum fitness corresponding to $\mathrm{m}^{*}$, maternal optimum; $\mathrm{o}^{*}$, offspring optimum; $\mathrm{m}_{\mathrm{s}}{ }^{*}$ and $\mathrm{m}_{\mathrm{i}}{ }^{*}$, original maternal optima for large (genetically superior) and small (inferior) offspring respectively; $\mathrm{s}^{*}$, new maternal optimum for a large offspring with superior genetic make-up; $i^{\star}$, new maternal optimum for the small (inferior) offspring; $\mathrm{m}_{\mathrm{e} 1}{ }^{{ }^{*}}$ and $\mathrm{O}_{\mathrm{e} 1}{ }^{*}$, maternal and offspring optimum in environment $1 ; \mathrm{m}_{\mathrm{e} 2}{ }^{{ }^{*}}$ and $\mathrm{o}_{\mathrm{e} 2}{ }^{{ }^{*}}$, maternal and offspring optimum in environment 2. The maternal optimum ( $\mathrm{s}^{\star}$ ) deduced from the sigmoidal curve (E) is greater than the expected $\mathrm{m}^{*}$ from a conventional $\mathrm{SF}$ curve (A). This greater $\mathrm{m}^{\star}$ from a sigmoid in (E) is similar to the higher maternal optimum for superior offspring $\left(\mathrm{s}^{\star}\right)$ in (B). Maternal controls (green shaded gradient) and zygotic controls (blue shaded gradient) on offspring size are indicated in (B-E), and all are suggesting that it is only when offspring size decreases below $\mathrm{m}^{\star}$ that maternal controls become strong. However, the nature of maternal-zygotic conflicts near $\mathrm{m}^{*}$, and how it shapes the SF curve remain open questions today. 
from the maternal parent as possible (pushing $\mathrm{m}^{*}$ toward $\mathrm{o}^{*}$ in Figure 1A). We note that the SF model closely parallels the optimal foraging model of Charnov (1976; The Marginal Value Theorem or MVT). In the MVT model, energy gain per unit time decreases as a function of time spent in a single patch, and the forager is predicted to leave the patch when the foraging rate (the slope of the energy gain curve) equals the mean foraging rate in the environment. The SF model describes parental investment into offspring and profit in terms of parental fitness (through offspring survival), whereas the MVT model describes investment in terms of time as well as energy spent foraging, with energy gained as profit.

Maternal- and offspring-specific optimal sizes, as predicted by the SF model (Figure 1A), create a conflict between parent and offspring, which raises the important issue of maternal vs. zygotic control over reproductive resource allocation (see below; Trivers, 1974; Uma Shaanker and Ganeshaiah, 1997). This parent-offspring conflict becomes even more complex when there is "sibling rivalry" or competition among many offspring of the same mother for maternal resources (Ganeshaiah and Uma Shaanker, 1988), as can happen during development of the offspring on the parent or after birth in animals with parental care. While competition between animal offspring may be active and even include direct fratricide, competition between sibling seeds in plants is more likely to be passive, via the exhaustion the maternal resource pool (but see the section on Endosperms). Importantly, the nutrient drawing ability (Uma Shaanker et al., 1995) of a seed is a function of its size: bigger seeds can invest more resources into resource drawing, and by doing so may overcome maternal controls and create a resource shortage for smaller seeds. When the offspring demands become overwhelming, the parent plant may selectively abort "inferior" embryos to ensure survival of a few offspring (Uma Shaanker et al., 1988; Pélabon et al., 2015; Figure 1B) and thus increase parental fitness (Haig, 1990; Vaughton and Carthew, 1993). Similarly, some animals selectively starve the weakest offspring when resources become limited after oviposition or birth (Lack, 1954; Ricklefs, 1965; Klopfer and Klopfer, 1973).

By selectively aborting or starving inferior offspring (by exerting direct control over offspring number), the parent will also sacrifice some of its control over the size of the remaining offspring. This is because the surviving offspring will receive more resources, grow bigger, and thereby (in the case of seeds) increase their nutrient drawing ability, meaning that zygotic control becomes stronger. On the other hand, shifting resources from inferior to superior offspring is also in the parent's own best interest. Theoretical models show that, when offspring vary in genetic quality, the maternal optimum for the size of highquality offspring ( $s^{*}$ in Figure 1B) is greater than the classical optimum in the SF model $\left(\mathrm{m}_{s}^{*}\right)$, and the maternal optimum for low-quality offspring is lower ( $\mathrm{i}^{*}$ vs. $\mathrm{m}_{i}^{*}$; Temme, 1986; Haig, 1990). This argument requires some mechanism of postzygotic recognition of genetic quality by parents. Little is known about such mechanisms, but offspring size is a very reasonable proxy for genetic quality, and indeed, all known instances of selective abortion (in plants) and starvation (in animals) involve elimination of the smallest among competing siblings (e.g., Melser and Klinkhamer, 2001; Mock, 2004). Furthermore, there is evidence that seeds generated from cross-fertilization (presumably of higher quality) tend to be larger than those from self-fertilization (e.g., Wingard, 1927; Shi et al., 2005; Petit et al., 2009). There is also some evidence to suggest that maternal genetic quality determines the extent of selective abortion in plants (e.g., Kärkkäinen et al., 1999). Yet, we do know what role paternal genetic quality plays in determining offspring fitness. More specifically, we do not know how the maternal genome discriminates between offspring that are superior due to better quality eggs and those that are superior due to better quality pollen. The relevance of "genomic imprinting" and the relative influence of paternal and maternal genomes in zygotes is beyond the scope of this discussion.

The SF model depends on two critical assumptions- (a) an optimum fraction of available total resources should be invested in reproduction such that it maximizes lifetime reproduction of a parent and (b) the resource pool is a homogenous entity, which parents invest to determine offspring size. While point (a) is intuitively true, resources are often heterogeneous. For example, plants require both carbon and nitrogen, and the availability of these two components may vary over the course of a season. McGinley and Charnov (1988) developed an extension of the SF model that predicts optimal seed size as a function of the carbon-to-nitrogen $(\mathrm{C} / \mathrm{N})$ ratio. In Figure $1 \mathrm{C}$, we provide a slightly modified interpretation of this model, with the aim of highlighting the role of changing $\mathrm{C} / \mathrm{N}$ ratio through the seasons on seed size. While the distinction between carbon and nitrogen acknowledges resource heterogeneity, the changing $\mathrm{C} / \mathrm{N}$ ratio identifies resource availability, and the two are inextricably linked. For a given $\mathrm{C} / \mathrm{N}$ ratio (which the maternal plant cannot alter), there is an optimum allocation to individual seeds, just as in the classical SF model. However, different $\mathrm{C} / \mathrm{N}$ ratios lead to different optima. More precisely, increasing the $\mathrm{C} / \mathrm{N}$ ratio is predicted to increase seed carbon content (and hence size) and decrease seed nitrogen content, whereas decreasing the $\mathrm{C} / \mathrm{N}$ ratio has the opposite effect of reducing seed size while increasing nitrogen content.

While some empirical studies show limited or no effect of C/N ratio on seed sizes (Uma Shaanker et al., 1988; Lalonde, 1991), the most convincing evidence supporting a role of $\mathrm{C} / \mathrm{N}$ comes from elevated $\mathrm{CO}_{2}$ experiments (atmospheric $\left[\mathrm{CO}_{2}\right]>$ $700 \mathrm{ppm}$ ) on crop plants. Both seed size and numbers generally increase after $\mathrm{CO}_{2}$ fertilization (e.g., Jablonski et al., 2002). Increases in seed size are attributed to greater carbon fixation through photosynthesis under elevated $\mathrm{CO}_{2}$, while increases in seed number are attributed to increased mobilization of nitrogen from leaves to seeds. This is surprising given that nitrogen is often a limiting factor for plant growth, and this limitation is expected to be enhanced under elevated $\mathrm{CO}_{2}$. But, the results are not that surprising when we take into account greater water use efficiency and greater photosynthetic rates in plants under elevated $\mathrm{CO}_{2}$, and this is despite decreases in leaf nitrogen content (Jablonski et al., 2002; Hikosaka et al., 2011). The second and third crop of flowers and seeds may become small since carbon fixed through photosynthesis declines with plant age (because of senescence), but seed numbers may be maintained since nitrogen supply can 
be ensured through continued remobilization of nitrogen from senescing leaves to seeds. A decreasing $\mathrm{C} / \mathrm{N}$ ratio over the course of a season may thus explain why, in many species, seed size decreases over the course of a season (e.g., Salisbury, 1942; Cavers and Steel, 1984; McGinley and Charnov, 1988).

It needs to be emphasized that resource or nutrient limitation is one of many different types of sub-optimal (harsh) environments experienced by plants, and plant response may be different for a different type of harsh condition. A key prediction of the SF model is that the maternal optimum $\mathrm{m}^{*}$ is independent of the total amount of resources invested in offspring (i.e., reproductive effort; Venable, 1992) but is likely to vary between different environments. Hence, offspring size should be adaptively adjusted by the mother due to $G$ $\times \mathrm{E}$ interactions. A simple example is shown in Figure 1D (after Einum et al., 2004), where an unfavorable environment (environment 1 in Figure 1D) is characterized by a higher minimum viable size and lower overall offspring fitness, which selects for larger offspring (increased $\mathrm{m}^{*}$ ).

In the classical SF model, the offspring size-vs.-fitness function is a horizontal line below the viability threshold, followed by a unipolar convex curve representing diminishing returns. However, it seems unrealistic that diminishing returns should set in immediately after the size viability threshold, especially since increasing seed size increases nutrient drawing ability (which suggests that the curve should have an early exponential-or at least concave-part). Thus, the SF curve is more appropriately represented as a sigmoid (Figure 1E). Therefore, the offspring size-vs.-fitness relationship might be more appropriately represented by a sigmoid function (Figure 1E). Like the classical SF function, a sigmoid predicts an intermediate maternal optimum situated in the convex part of the function. Yet, exponential decrease or increase in fitness of seeds belonging to size classes close to a maternal optimum (as seen in a sigmoid) suggests strong selection pressures on seed size optimization. The sigmoid accommodates the idea that maternal control increases above a certain offspring size (for animal examples see Levitan, 2000; Reeve et al., 2000; Jørgensen et al., 2011). The sigmoid is consistent with the concept of sibling rivalry (depressing the fitness of small offspring) and parental preference for superior offspring (maternal optimum $s *$ is greater than $m *$ in Figure 1E). However, the assumption that big offspring always show greater fitness compared to small offspring may not hold in some special cases where developmental and habitat constraints play a role. Hendry et al. (2001) evaluated the impact of developmental stage (pre- vs. post-hatching) on offspring fitness as a function of size. They proposed a version of the SF model where eggs larger than an optimum size $\left(\mathrm{o}^{*}\right)$ experience diminishing fitness (Figure 1F). Theoretically, larger hatchlings from bigger eggs are expected to show higher fitness in favorable environments. Nonetheless, big eggs may not survive to hatchling stage either due to space constraints for incubation (lack of parental care) or suffer from asphyxia in sub-optimal aquatic habitats. In such cases, optimum offspring size for maximizing maternal and offspring fitness are likely identical (contrast Figures 1D,F). We will reassess shifts in maternal optima in greater detail under the empirical section dealing with environmental responses of offspring size and number tradeoff.

\section{PLANTS}

The origin(s), evolution and diversity of seeds themselves are thought to be critically important in the domination of seed plants in terrestrial ecosystems. Seeds ensured the safety of the stationary female gametophyte (ovule), and led to novel mechanisms of long-distance dispersal (Nathan et al., 2008). In conjunction with breakthrough adaptations such as efficient xylem transport and stomatal mechanisms (e.g., Crepet et al., 1991), diverse mechanisms of seed tolerance to desiccation (Baskin and Baskin, 1998) allowed seed plants to overcome dispersal limitations on land and colonize drier geographic territories away from the tropical wet forests. Seed diversity is dramatic across the plant kingdom, and principal aspects of this variation are size and number.

\section{LIFE HISTORY CONSTRAINTS ON SEED SIZE AND NUMBER}

Plant form, habitat, ecophysiology, and reproductive modes are some of the higher-order life- history determinants of seed size and number, and these factors have both restricted variation and led to common trends within and between plant species and families. While these constraints are not directly related to the theoretical models presented earlier, they have a central place in our discussion, since it may turn out that explanations for observed trends in seed plants may lie in these deep life history constraints on reproductive strategies.

\section{Ovules}

Ovules are the progenitors of seeds in higher plants, and seed size is influenced by the thickness of their four anatomical layers, viz., integuments (outer protective layers of cells, also called testa), perisperm (outer endosperm), endosperm, and embryo (Bewley and Black, 1994). Variation in these four components manifests in the structural and morphological diversity of seeds, and each component likely has a different impact on the relationship between seed size and fitness, although these have not been assessed individually until now. Ovules in gymnosperms are much larger than those in angiosperms (with some cycad ovules being $>600 \mathrm{~mm}$ in diameter), and on average, gymnosperm seeds are larger than angiosperms seeds (Moles et al., 2005; Linkies et al., 2010). The reduced size of angiosperm seeds (typically between 0.5 and $2 \mathrm{~mm}$ ) is linked to the evolution of the carpel, which encloses and protects the ovule and is argued to have reduced the structural costs of angiosperm reproduction (Lord and Westoby, 2012). Ovule size in angiosperms is also strongly constrained by flower size, since large flowers are expensive to build and maintain. In cases where angiosperm flowers did become large, natural selection appears to have favored a higher number of ovules per flower rather than increased ovule size (Endress, 2001; Greenway and Harder, 2007). Increase in ovule number per flower has also been attributed to the higher 
probability of receiving a high amount of pollen grains on a single (large) flower rather than an even spread of pollen grains on a greater number of flowers (Burd et al., 2009).

\section{Endosperm}

The origin, function and diversity of endosperms has a complex relationship with seed size and function in angiosperms ( $\mathrm{Li}$ and Berger, 2012). The endosperm is a specialized embryonourishing tissue and is one of the products of double fertilization, a unique feature of angiosperm reproduction (Baroux et al., 2002; Friedman and Williams, 2003). As a general trend, the endosperm is larger in primitive angiosperm clades and small or absent in younger clades. Consequently, the embryoto-seed ratio is significantly higher in younger clades than in primitive clades (Forbis et al., 2002). For example, in wheat, maize and other cereal crop plants, the endosperm constitutes more than $80 \%$ of total seed weight. In such plants, the size, capacity for dormancy, viability, durability and fitness of seeds is determined by the size of the endosperm and not that of the embryo (Martin, 1946; Bremner et al., 1963; also see Garcia, 2003, 2005). In contrast, in younger dicot families, such as cucurbits and orchids, the endosperm is reduced to a couple of layers of cells. It is argued that the endosperm in early angiosperms was a competing embryo that gradually evolved into an aborting, altruistic nourishing tissue (Friedman, 1995). There also is some evidence to suggest that the endosperm competes with the embryo for maternal resources until it is consumed by the developing embryo (Zhou et al., 2009; Sun et al., 2010). This suggests "sibling rivalry" between embryos and endosperms, although the role of endosperm in parent-offspring conflict and hence in the size-number tradeoff is still an unresolved question.

\section{Nutrient/Resource Quality and Quantity}

While the presence of an endosperm can be seen as a maternal strategy of offering parental care in absentia, an important factor often overlooked in simple seed size-vs.-number examinations is the calorific value of nutrition packed in seeds, which may or may not follow seed size (Levin, 1974; Lokesha et al., 1992). Seeds can store carbon and nitrogen in either cotyledons or endosperms as (a) starch, (b) proteins, or (c) lipids and oils, which may constitute more than $50 \%$ of carbon content in some oily seeds. Sugars can accumulate in seeds from the breakdown of lipids (via the glyoxylate cycle) or hydrolysis of starch, and both can support seed germination and seedling growth. Soluble oligosaccharides in seeds increase seed tolerance to oxidative stress, desiccation, chilling, and salinity stresses (Obendorf, 1997; Nishizawa et al., 2008). It is logical that large seeds can store larger amounts of all nutrients (starch, soluble sugars, and lipids), and hence be more resilient during periods of stress. Nutrition quality is also associated with seed dispersal mode. Wind- and animal-dispersed species produce lighter seeds with more fat than carbohydrate and protein content (Lokesha et al., 1992), as fat yields more energy per unit weight.

\section{Growth Form and Body Size}

A global phylogenetic analysis of land plants shows that growth form (whether a plant is a herb, shrub, or a tree) is the most significant determinant of seed size (Moles et al., 2005). Herbaceous plants (many are annuals) bear small seeds and fruits unless they are crawlers or climbers (Levin, 1974; Westoby et al., 1992). To bear large, heavy seeds and fruits a plant needs mechanical strength (lignification and secondary growth). Even within a given growth-form, seed size generally increases with body size (vegetative biomass), following allometric principles (Thompson and Pellmyr, 1989; Shipley and Dion, 1992). At another level, the production of large seeds needs more resources and more time (longer generations). Allometric principles are also shown to underpin the correspondence between leaf size and the size of reproductive appendages in trees. Perennial plants may overcome allometric limitations on seed size by increasing reproductive output over the entire lifespan of the parent (Venable and Rees, 2009), while herbaceous plants under severe competition for space and resources may evolve short generation times and production of a large number of small seeds (Aarssen and Jordan, 2001). It has been suggested that the diversity in seed size across plant lineages follows a positively skewed fractal distribution (Hegde et al., 1991), since the number of small habitats (dominated by herbs with small seeds) is far greater than that of large habitats (inhabited by trees with large seeds). Hence, the frequency distribution of habitats (space) may explain the frequency distribution of plant body size, and in consequence, seed size (Valen, 1973; Hegde et al., 1991; Damuth, 1998).

\section{Growth Rate}

Many forest species living in light-limited environments show a strong negative correlation (among species) between seed size and relative growth rate (RGR) during the early exponential phase of seedling growth (Shipley and Peters, 1990; Marañón and Grubb, 1993; Paz et al., 2005; Turnbull et al., 2012; later in life, RGR decreases with age in all plants, Poorter and Rose, 2005). Moreover, larger seeds, despite their low initial RGR, have higher growth potential and attain larger overall body sizes at full maturity (Turnbull et al., 2008, 2012; Aarssen, 2015), confirming the basic assumption of the SF model that large seeds have higher fitness than small seeds.

\section{Dispersal Mode}

Dispersal of offspring away from the parent plant is a fundamental means of reducing competition between parent and offspring, as well as among offspring. Dispersal may also aid offspring escape from a stressful (resource-limited) habitat. The earliest vascular plants, despite having succeeded in colonizing terrestrial habitats, continued to depend on water for the dispersal of haploid male and female spores, since at least one phase of their reproductive cycle, often the gametophyte, was aquatic. For various reasons (see Bateman and DiMichele, 1994 for a review), the female spore of multiple early vascular plant lineages became large (heterospory), and the dispersal of such megaspores became restricted. This later led to the evolution of seeds and the diversification of dispersal modes. Seed dispersal syndromes in angiosperms are associated with the phylogeny of fruit types, and they influence seed size (Moles et al., 2005; Lorts et al., 2008). Wind and animal dispersed species that 
produce seeds with specialized appendages (such as wings and fleshy coats) tend to have smaller seeds than those dispersed through passive or explosive mechanisms with limited dispersal range (Lokesha et al., 1992; Parciak, 2002). Costs of dispersal increase with increasing seed size. Interestingly, some plants have evolved a strategy to not invest in dispersal altogether, since the probability of seedling survival is very low. The best examples are seen in viviparous mangrove plants. Vivipary is a rare form of parental care in plants (occurring in only 20 genera and 13 families, Elmqvist and Cox, 1996), where the parent plant bears a few large seeds that mature and germinate while still attached to it. Free from the constraint of optimization for dispersal, the mother plant can invest in large seeds. Indeed, large mangrove seeds have some of the longest maturation times (from pollination to seedling establishment) known in the plant kingdom (up to several years). Thus, the cost of maintaining non-dormant seeds and seedlings is likely to be huge for the mother plant, leading to a strategy of optimizing seed numbers. Mangrove plants achieve offspring number optimization either by premature abscission of damaged seedlings or selective abortion of small seeds (Farnsworth and Ellison, 1997; Saenger, 2002).

\section{GENETIC CONTROLS ON SEED SIZE AND NUMBER: LESSONS FROM ARABIDOPSIS}

At a macrogenomic level, a positive correlation between genome size and seed size is observed both within and between phylogenetic clades, especially in angiosperm lineages with small genomes and within the pine clade in gymnosperms (Thompson, 1990; Beaulieu et al., 2007). Existing arguments to explain codivergence of genome size and seed size are inadequate and inconclusive (Beaulieu et al., 2007), despite a broad allometric agreement between genome size and other phenotypic properties, stronger at the cellular level and weaker at higher bodily organization in plants (Knight and Beaulieu, 2008).

While it is important to understand genome-phenome associations across plant families, answering such questions may not address the diversity in seed size and numbers at the level of species and ecotypes, which are subtler and likely regulated by microgenomic interactions. We do not yet have enough information, especially in non-model plant systems, for an overarching genetic paradigm of seed size, shape and number regulation (Orsi and Tanksley, 2009; Gegas et al., 2010; Fang et al., 2012). However, some insight is offered by model systems such as Arabidopsis thaliana (hereafter simply Arabidopsis). Arabidopsis has a fast generation time, and possesses a vastly underappreciated natural genetic and phenotypic variation (Koornneef et al., 2004; Singh et al., 2015). However, the microscopic size of Arabidopsis seeds poses methodological difficulties in characterizing seed phenotype, which prevented it from being a model to investigate evolutionary ecology of plant reproductive strategies. The advent of digital techniques to precisely quantify seed characteristics has led to closer examinations of seeds in Arabidopsis mutants (e.g., Herridge et al., 2011). In their study of 64 different mutant lines, Van Daele et al. (2012) reaffirmed a negative correlation between seed size and seed number. A re-examination of the same data shows that the mean seed size in Arabidopsis has limited variation $(0.1 \pm 0.02 \mathrm{~mm})$ across all mutant lines (Figure 2B). Total seed number per plant showed a 10 -fold range (400-4,000, including outliers) while total seed weight per plant showed a 5 -fold range (50-250 mg). However, there was no correlation between total seed weight and total seed number or mean seed size (Figures 2B,C): plants with high total seed weight had heavier (denser), not more or larger, seeds than those with low total seed weight (probably due to differences in oil content, see section on nutrient quality and quantity above). We also found that there was zero correlation between total rosette (leaf) area and total seed weight and similarly there was no relationship between rosette area and total seed number per plant (Figures 2A,D). While photosynthesis and general metabolism in leaves may have been compromised in some Arabidopsis mutants leading to differential seed production, the complete lack of any relationship between leaf mass and seed mass or number remains to be explained.

Research on genetic controls on seed size has been reviewed extensively in recent years (Sundaresan, 2005; Linkies et al., 2010; Sun et al., 2010; Li and Berger, 2012). Instead of providing a descriptive account of genes regulating seed size, we present an illustrative summary of seed size variation in Arabidopsis mutants (Figure 3; Table 1). The data suggest that genes acting in maternal tissues have less impact on seed size than genes operating directly in zygotes (embryos), which can be partly due to the bias in the data set, since we know more about genes acting in maternal tissues. It is equally significant to note that the percent increase in seed size due to loss-of-function mutations in genes whose normal function is to restrict seed size (irrespective of whether they act in maternal or zygotic tissue) is significantly greater than the percent decrease in seed size due to loss-of-function in genes that are actively promoting larger seeds.

Maternal genes involved in restricting the size of inferior (small) seeds will certainly be different from those involved in diverting more resources toward superior (large) seeds. Furthermore, it is well established that during plant development (also in animals), maternal genetic controls wean and are successively replaced by zygotic controls (e.g., Baroux et al., 2008). What will be important to establish, however, is whether increases in the size of superior seeds are due to a weakening control of maternal genes restricting seed size or due to overexpression of zygotic genes promoting seed size (Figure 3).

Arabidopsis mutants have provided valuable insights into specific genes and gene-networks that control seed size (North et al., 2010). In this context, it is important to distinguish between genes that exclusively control seed size and those that indirectly influence seed development through their effects on global resource allocation and organ size within a plant (Mizukami and Fischer, 2000; Adamski et al., 2009; Van Daele et al., 2012). Analysis of genes directly involved in seed-size control in Arabidopsis mutants invariably show that variation in seed size is not linked to seed number (Zhou et al., 2009); In other words, mutations altering seed size do not pleiotropically alter seed numbers. QTL analysis of natural variation also suggests 


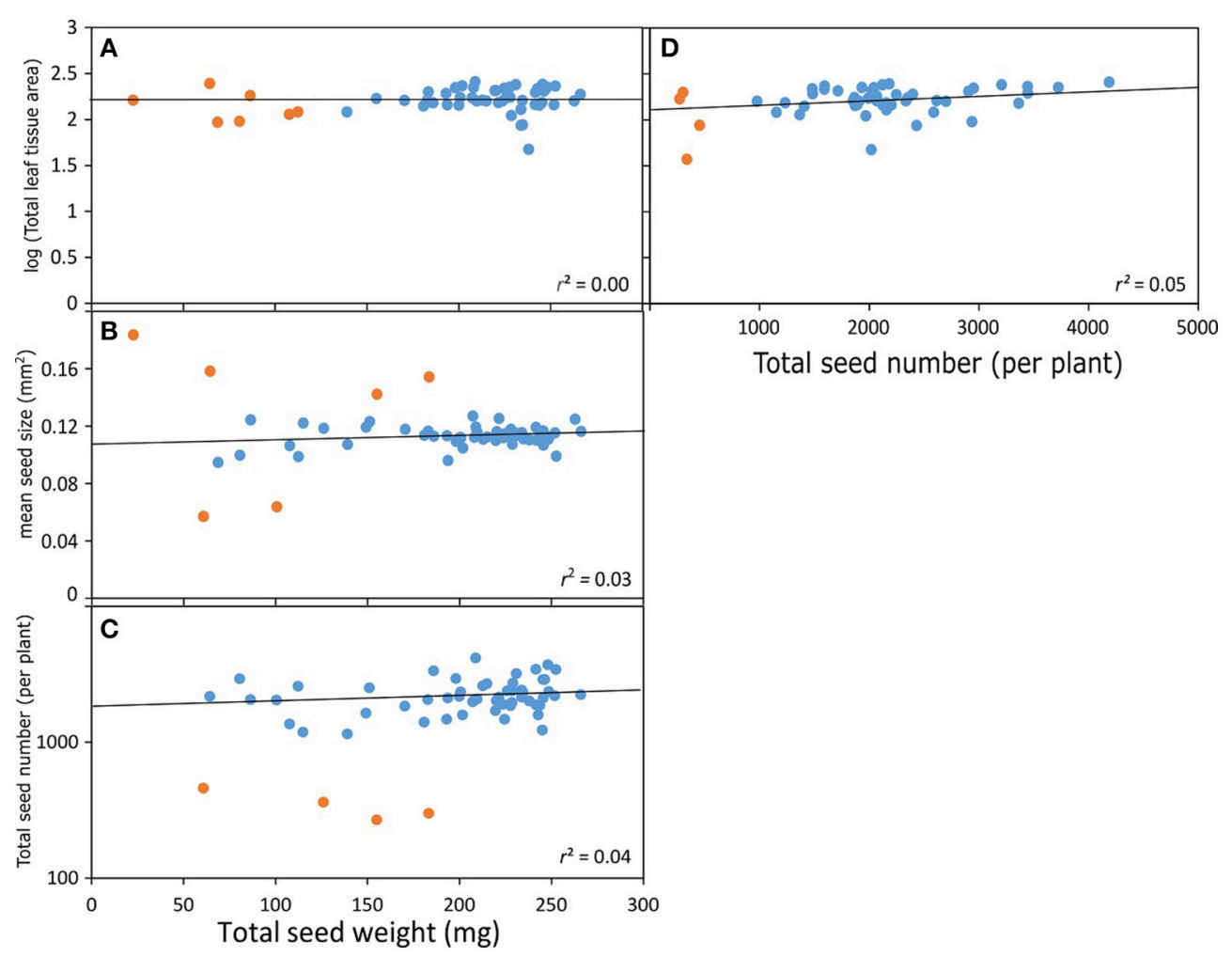

FIGURE 2 | Relationships between seed traits in Arabidopsis mutants (data from Van Daele et al., 2012). Total seed weight vs. (A) Total seed number per plant, (B) mean seed size, (C) total leaf tissue area. (D) Total seed number vs. total leaf tissue area. The orange dots correspond to a minority of outliers (mutants with extreme trait values) in each plot, whose inclusion into the dataset alters these relationships significantly. It is not a surprise that some of these orange data points include mutants and mutations in genes directly associated with seed size regulation. Regression lines and coefficients of determination are calculated without these outliers.

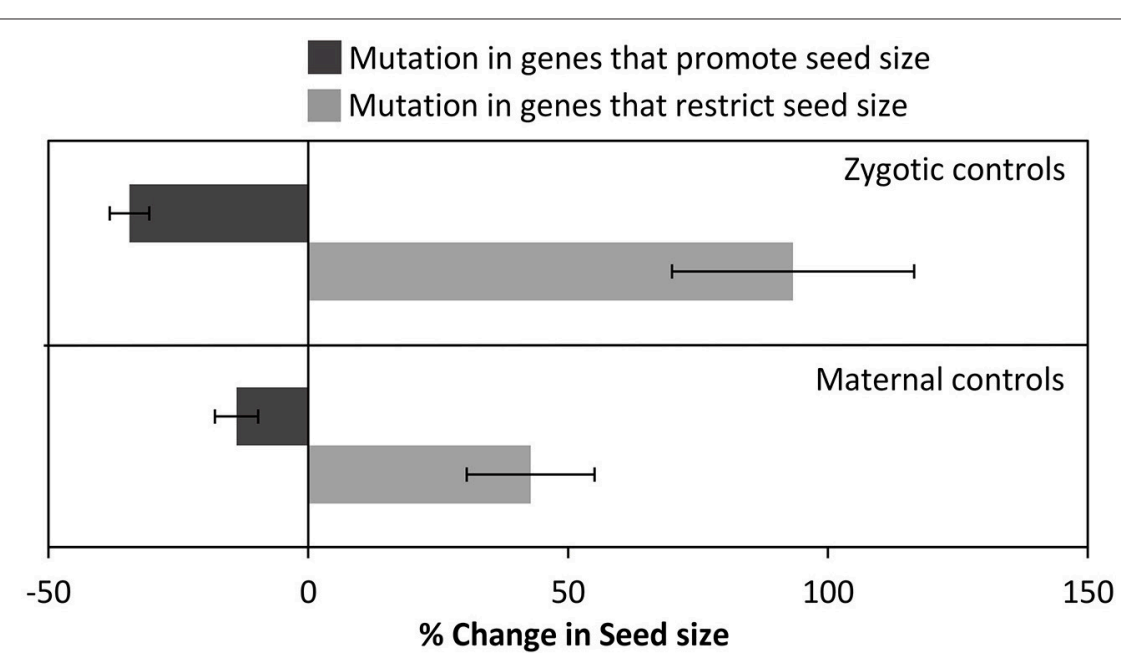

FIGURE 3 | Genetic controls on seed size in Arabidopsis thaliana. The table summarizes mutations in specific genes known to be directly involved in regulating seed size. The bar graph summarizes and differentiates the \% change in seed size due to mutations in maternal and zygotic tissues.

that genetic factors controlling seed size and seed numbers are situated in different parts of the Arabidopsis genome (on different chromosomes) and can evolve independently (Gnan et al., 2014).
We know a lot less about the genes involved in regulating seed number than about genes regulating seed size. Some of the genes regulating seed numbers are associated with regulation of sizes 
TABLE 1 | Maternal and zygotic (genetic) controls on seed size: Insights from Arabidopsis thaliana.

\begin{tabular}{|c|c|c|c|c|}
\hline Gene & Function & Mutant & Mutant seed size & References \\
\hline \multicolumn{5}{|c|}{ GENES ACTING IN THE ZYGOTE } \\
\hline SHB1 & $\begin{array}{l}\text { Short hypocotyle under blue 1; a transcription } \\
\text { coactivator; Promotes embryo cell proliferation }\end{array}$ & $\begin{array}{l}\text { SHB1 overexpression } \\
\text { shb1-D gain of function }\end{array}$ & $\begin{array}{l}\text { Increases } \\
\text { Increases }\end{array}$ & Zhou et al., 2009 \\
\hline $\begin{array}{l}\text { AHK2, AHK3, } \\
\text { AHK4 }\end{array}$ & $\begin{array}{l}\text { Arabidopsis Histidine Kinase Receptors involved } \\
\text { in cytokinin signaling; restricts embryo size }\end{array}$ & $\begin{array}{l}\text { ahk2, ahk3, ahk4 triple } \\
\text { mutant }\end{array}$ & Increases & Riefler et al., 2006 \\
\hline $\mathrm{IKU} 1$ and IKU2 & $\begin{array}{l}\text { Leucine rich repeat (LRR) kinase directly } \\
\text { regulates endosperm size }\end{array}$ & iku1, iku2 (also haiku 1, 2) & Decreases & $\begin{array}{l}\text { Garcia, 2003, 2005; } \\
\text { Wang et al., } 2010\end{array}$ \\
\hline SHB1 & $\begin{array}{l}\text { Promotes embryo cell proliferation by increasing } \\
\text { cell number and expansion }\end{array}$ & shb1 & Decreases & Zhou et al., 2009 \\
\hline EXS & $\begin{array}{l}\text { LRR kinase that affects the size of the embryo } \\
\text { cell size, by affecting cell size without any } \\
\text { accompanying effect on number }\end{array}$ & exs2, exs 3 & Decreases & Canales et al., 2002 \\
\hline \multicolumn{5}{|c|}{ GENES ACTING IN MATERNAL TISSUES } \\
\hline APETALA 2 & $\begin{array}{l}\text { TF involved in Flower development and floral } \\
\text { organ identity }\end{array}$ & apa2 & Increases & $\begin{array}{l}\text { Jofuku et al., 2005; Ohto } \\
\text { et al., } 2005\end{array}$ \\
\hline UPF 1 & $\begin{array}{l}\text { RNA helicase involved in non-sense mutation } \\
\text { mediated RNA decay }\end{array}$ & upf1/lba1 & Increases & Yoine, 2006 \\
\hline MNT/ARF2 & $\begin{array}{l}\text { Megaintegumenta, Auxin Response Factor2 is a } \\
\text { TF repressing cell division in integuments }\end{array}$ & mnt/arf2 & Increases & Schruff, 2005 \\
\hline EOD3 & $\begin{array}{l}\text { Cytochrome P450 monoxygenase that promotes } \\
\text { cell expansion in maternal tissues }\end{array}$ & eod3-1D Gain of function & Increases & Fang et al., 2012 \\
\hline KLU & $\begin{array}{l}\text { Cytochrome P450 KLUH promotes cell division in } \\
\text { inner integuments of ovules }\end{array}$ & KLU overexpression & Increases & Adamski et al., 2009 \\
\hline EOD3 & $\begin{array}{l}\text { Cytochrome P450 monoxygenase that promotes } \\
\text { cell expansion in maternal tissues }\end{array}$ & eod3 & Decreases & Fang et al., 2012 \\
\hline TTG2 & $\begin{array}{l}\text { TF belonging to WRKY family, Transparent testa } \\
\text { glabra2, promotes cell expansion in integuments }\end{array}$ & $\operatorname{ttg} 2$ & Decreases & Garcia, 2005 \\
\hline KLU & $\begin{array}{l}\text { Cytochrome P450 KLUH promotes cell division in } \\
\text { inner integuments of ovules }\end{array}$ & klu & Decreases & Adamski et al., 2009 \\
\hline
\end{tabular}

of floral meristems and inflorescences. Maize mutants producing more seeds (kernels) per row do not produce seeds that are smaller than those from wild, control groups (Bommert et al., 2013), suggesting that the tradeoff between seed size and number within a species need not hold always. It is also possible that genes involved in initial floral differentiation predetermine the number of ovules per ovary and number of flowers per inflorescence, thus impacting seed number through pleiotropic effects (Huang et al., 2013), without causing an evolutionary tradeoff with size. Some other genes such as APETALA2 and AHKs (cytokinin signal receptors) have the most dramatic impact on not only seed size but also seed number through their global impact on resource reallocation within a plant (Ohto et al., 2005; Riefler et al., 2006).

Overall, our findings in Arabidopsis are consistent with the notion that diversity in seed size is not as great as that in seed number per plant within a species (Harper, 1967), suggesting seed number to be less responsive to selection. This finding also suggests that the SF model may be right in assuming that the optimization of offspring size is independent of selection pressures on reproductive effort (Venable, 1992; but see the section on environmental factors). Thus, mechanisms to restrict seed size (and not numbers) might have become prominent and diversified through the course of seed plant evolution.

\section{ENVIRONMENTAL FACTORS INFLUENCING REPRODUCTIVE STRATEGIES IN SEED PLANTS}

Many functional traits affecting the size-number tradeoff are strongly influenced by environmental factors. These traits can respond to environmental changes either through phenotypic plasticity, or through rapid evolution, and they do not have the evolutionary inertia that is typical of most life history traits (discussed earlier). While shortterm physiological or phenotypic adjustments can often can be classified as stress-responses, they also provide new raw material for natural selection through epigenomic changes inherited by offspring produced while the suboptimal conditions prevail. If the same environmental conditions persist over a longer term (several thousand generations), for example due to a shift in climate, then in an evolutionary sense what was stressful to the ancestors of the past becomes the new norm for those progenies that manage to survive until the present. Therefore, analysis of stress responses is relevant also in the light of larger-scale evolutionary trends. In the following section, we discuss various environmental factors that influence plant reproductive strategies. 


\section{Light}

As mentioned earlier, plant growth form (a life history trait) is a significant determinant of seed size, especially at the coarse scale (herbs vs. trees). The most important abiotic determinant of growth form in plants is light. To understand evolutionary trends in seed size variation and the mechanisms of size regulation, it is important to consider the influence of light on reproductive strategies at a finer scale, for example herbs of different shapes and sizes. Herbaceous plants from forest understories can be either shade-tolerant or show a shade avoidance syndrome (SAS). Shade avoidance dramatically alters plant form by stem elongation and reduced branching due to apical dominance (AD). Depending on the extent of competition for light in a given habitat, $\mathrm{AD}$-induced suppression of axillary buds may translate into fewer branches, and thus reduced flowering and seed production (Aarssen, 1995; Irwin and Aarssen, 1996). Manual removal of the apical bud in species that do not show SAS and grow in open landscapes causes a significant increase in seed weight, although seed numbers remain unaffected (Naber and Aarssen, 1998). The reason may be that, since these plants lack apical dominance, suppression of apical growth does not lead to increased lateral branch growth. Hence, the pool of carbon that would otherwise have been invested in apical growth is likely diverted to seeds, leading to greater seed weight without altering seed numbers. More recent research in crop plants has focused on $\mathrm{AD}$ and $\mathrm{SAS}$ associated reduction in grain size and number, and the underlying genetic mechanisms, since neighbor-shading is a feature of high density- monocultures (Gommers et al., 2013).

A study of the relationship between seed size and the extent of shade tolerance in forest trees showed that fast-growing, deciduous, apically dominant, SAS trees bear the lightest seeds, while slow-growing, evergreen, shade-tolerant trees bear the heaviest seeds, and the trend is conserved both within and between angiosperms and gymnosperms (Reich et al., 1998). The same trend was experimentally shown much earlier at a smaller scale, and it was hypothesized that large seed size provides an advantage in shaded environments by providing greater nutrient reserves to opportunistically exploit canopy gaps and by supporting seedling survival when photosynthesis is lightlimited (Leishman and Westoby, 1994). In addition, the larger seedlings grown from large seeds retain a sufficient advantage over fast-growing small seeds of SAS plants in dark understories of tropical forests (Leishman and Westoby, 1994). The positive relationship between shade tolerance and seed size, and that between body size and seed size, can also arise due to the greater lipid content (nutrient quality) of large tree seeds as compared to small seeds of herbaceous plants (Levin, 1974). An analysis of multiple functional traits in more than 100 neotropical forest species provided further proof that light response and seed size are intricately linked and that light availability has played an important role in the evolution of seed size (Rüger et al., 2012).

\section{Responses to Changes in Environment}

Life history constraints including seedling and adult growth form (determined by competition for light among other factors) in most cases provide a sufficient basis to explain the variation in seed size vs. number seen across different species and families. However, many plant species show intraspecific variation in seed size, which often covers several orders of magnitude (Thompson and Pellmyr, 1989; Obeso, 1993; Méndez, 1997, for examples see Greenway and Harder, 2007). Reconciling such large within-species variation with the classical notion of seed-size optimization has so far not been possible. Models discussed earlier (Figure 1) that incorporate sibling rivalry, nutrient availability, and genetic quality of offspring have to an extent succeeded in showing how variation can persist within populations, but they do not adequately explain why large variances are maintained if a habitat/habit-specific optimum exists. Unfortunately, many studies do not report seed number variation, and this lack of data has hindered hypothesis testing. Therefore, it is important to consider how plant reproduction is affected by short-term responses to changes in environmental factors beyond those in light.

Within species, larger seeds have an advantage over smaller seeds in low-light environments, and generally by conferring greater desiccation tolerance (Lönnberg and Eriksson, 2013) and leading to greater seedling vigor and survival (Moles and Westoby, 2004). Some studies suggest that large seeds are more viable than small seeds, and the probability of seedling emergence increases with increasing seed size (Ben-Hur et al., 2012; BenHur and Kadmon, 2015), although such studies have focused on variation between rather than within species. This trend is broadly interpreted in the context of a competition-colonization tradeoff, where large seeds have a competitive advantage due to superior ecophysiological performance, while small seeds (in large numbers) exploit opportunities in less competitive environments. Under the assumption that large seeds confer greater tolerance to short-term stresses, theoretical models have argued that high-fecundity plants with small seeds thrive in nutrient-surplus conditions and plants producing high-tolerance large seeds win in stressful environments (Muller-Landau, 2010; in the context of interspecific variation).

Most of the data on seed number and quality under stress stem from agronomic studies, but such studies are not meant to answer questions pertaining to the evolution of reproductive strategies. In the following section, we discuss some broad trends in seed size-and-number variation and responses to short-term stress in non-crop plants. Unlike cereal crops, leguminous plants possess a simple and uniform ovary containing a few large seeds, making them ideally suited for experimental investigations on seed ecology (van der Pijl, 1969; Ganeshaiah and Uma Shaanker, 1991). A study looking at responses of a legume subjected to various forms of abiotic stress showed that shortage of nutrients, drought, and high temperature stresses, while not significantly affecting seed number, all caused a decrease in both the mean and variance of seed size, whereas seed numbers did not differ significantly (Wulff, 1986), implying stronger maternal controls and more efficient optimization (Figure 4A). A stress-induced reduction in seed size is confirmed by other studies and appear to be general: For example, stress due to competition between maternal plants growing at high density may make parents invest limited available resources in a large number of small seeds (Larios and Venable, 2015), and a study on 30 herbaceous annuals showed that seed number was more stable than seed size under changing levels of moisture stress (Germain and Gilbert, 2014). In evolutionary terms, these results are consistent with 

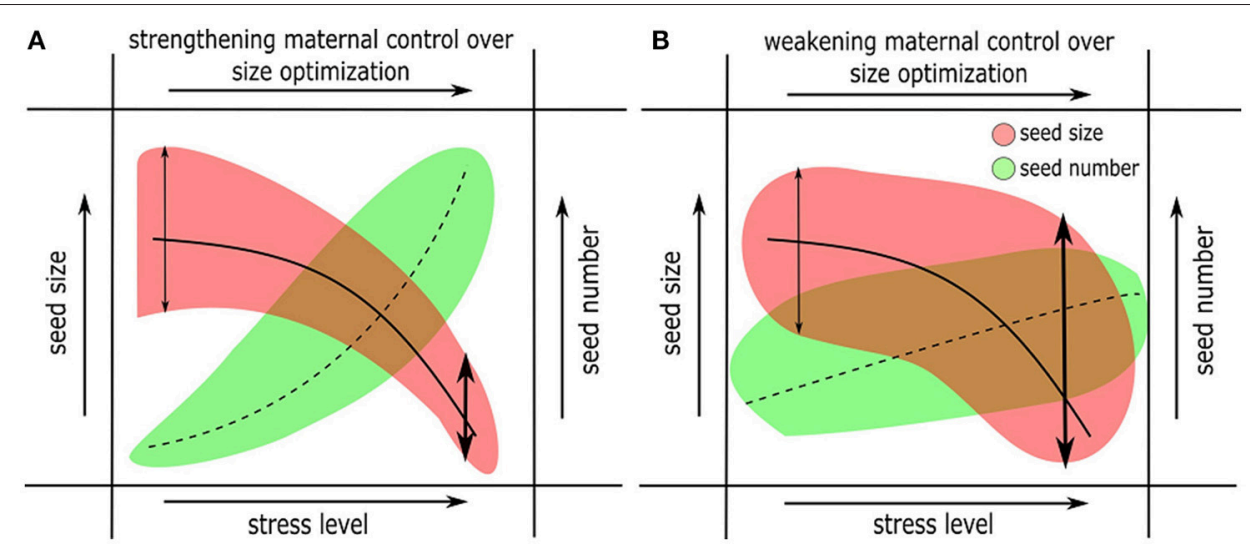

FIGURE 4 | Changes in offspring size and numbers in response to changes in environmental factors (sub- optimal or stressful conditions). Two alternative scenarios are represented. (A) Strengthening maternal control (vis-à-vis zygotic controls) over offspring size optimization, and (B) Weakening maternal control over size optimization. Scenario (A) combines the hypotheses presented in the models in Figures 1B,C (derived from the classical Smith-Fretwell model), where resource limitation causes strengthening of maternal controls over size optimization. Scenario (B) means a more complicated interaction between maternal, zygotic genetic controls over size optimization and their environment. The response of offspring number in (A) is expected to increase and in (B) it is less predictable under harsh conditions.

the notion that less stressful environments favor larger and fewer seeds, while higher risk of mortality in harsher habitats favors the production of more and smaller seeds (Volis et al., 2002).

Unlike mean seed size, seed size variance does not always decrease in stressful environments. In contrast to the results by Wulff (1986, discussed above), other studies show that seed size variation significantly increases under nutrient limitation (Halpern, 2005), thus indicating weaker maternal controls (Figure 4B). Harper and Ogden (1970) in their seminal paper had reported a similar pattern for a legume where increasing stress levels severely impacted phenology of flowering and increased variance in plant form and seed production. The latter results support the theory that changes in the environment beyond a species-specific tolerance threshold cause developmental instability and lead to new offspring phenotypes (Simons and Johnston, 1997). Some of these observations can be discussed under the framework of bet-hedging theory (Slatkin, 1974). In other words, plants may produce a large number of small seeds (with a greater potential for dormancy, see below) under suboptimal conditions, such that those seeds germinate randomly over a long period of time and at least some of them germinate when favorable conditions return (Cohen, 1966; Simons, 2011). Some observations indicate that within-species variation in seed size is positively correlated with the extent of seedling survival and stress tolerance (Westoby et al., 2002; Coomes and Grubb, 2003). However, empirical evidence for bet-hedging is rare (Tielbörger et al., 2012; Gremer and Venable, 2014), and the relationship between size and number of offspring in the context of bet-hedging is unknown.

It is not clear whether stress-induced reduction in seed size is always adaptive and/or advantageous (and the answer is likely to depend on the type of stress). Small seeds may have a number of advantages: The study by Larios and Venable (2015) provides evidence for greater dispersal distances, suggesting a tradeoff between dispersal and competitive ability. Small seeds can also have an advantage due to a greater potential for dormancy (Venable and Brown, 1988; Rees, 1996) or lower probability of predation (Andresen and Levey, 2004). Similarly, changes in environmental conditions (including soil nutrients) can alter the quantity and quality of stored nutrition in seeds (Halford et al., 2015). For example, in wild Arabidopsis, a greater gain in seed volume than seed weight under high light exposure is attributed to a doubling of seed oil content, which is less dense than carbohydrates and proteins (Li et al., 2006). Other studies show that the ratio of starch to lipid in seeds could be altered under stress (Ali et al., 2012), which may affect offspring fitness. Other factors such as seed to seed coat ratio could play a significant role in determining stress tolerance and viability of seedlings (Hill et al., 2012). Therefore, plants may produce small seeds with high calorie nutrition (lipid rich), or with a thicker seed coat, or with activate mechanisms of dormancy, and such seeds are likely as viable as large seeds under stressful conditions. However, there are disadvantages as well, since small seeds are generally more vulnerable to early mortality (Daws et al., 2007). If the stressful conditions persist for several generations, then offspring mortality can be very high (especially in the case of annuals), since all offspring originated from seeds smaller than that of their parents. It is hard to explain a plant's strategy to sacrifice a large number of offspring instead of investing in a few large tolerant offspring. Decreased and more stringently regulated seed size under stress (Figure 4A) suggests a possible "self-preserving strategy" (where reproduction is either postponed or reproductive effort is reduced) from the maternal plant and is expected to be more prevalent in perennial plants. A perennial maternal plant may exert extreme control over reproduction such that it produces no offspring during a season owing to prevailing "harsh" conditions. Therefore, maternal control over offspring size both theoretically and realistically extends all the way to zero size or no offspring (Figure 1). 
In annuals that are never exposed to multi-year stresses, maternal control may substantially weaken under stress, leading to erratic variation in seed size. The classical models argue that optimization of offspring size may be independent of parental reproductive effort. However, decrease in offspring size and increase in numbers under adverse conditions including resource limitation (Figure 4B, contrast Figure 1C) suggests alternative possibilities. Weaker maternal control over seed size optimization and the resultant increase in size variation can be beneficial in annuals under stress. A handful of larger seeds with increased desiccation tolerance may support seedling growth under nutrient limitation and may ensure survival of offspring. The response of seed nutrient quantity and quality to changing environments, and what impact they have on seed survival (longevity) and early seedling establishment are largely unknown. In all of these cases, seed number variation is the most difficult to predict, both due to lack of experimental data and because of complications due to variation in plant size, life span, number of branches, and overall health.

\section{ANIMALS}

Animals show a general trend toward reduction of fecundity and concomitant increase in offspring size associated with increasing organismal complexity (Brockelman, 1975). Both fecundity and offspring size generally increase with the size of the mother (Parsons, 1964; Roff, 1992; Honěk, 1993; Fox and Czesak, 2000; Shanbhag et al., 2003; Kolm et al., 2006a; Rollinson and Rowe, 2016), although exceptions exist (e.g., Fischer and Fiedler, 2001). Species for which no size-number tradeoff has been found typically show considerable variation in reproductive effort (Fox and Czesak, 2000). Many studies have reported conservatism in egg size, with greater variation in clutch size under varying environmental conditions (birds: Lack, 1954, 1968; fish: Scott, 1962; Hester, 1964; Fleming and Gross, 1990; mammals: Jordan et al., 1967; Stevenson-Hamilton, 2012; readers are referred to other focused reviews for more detailed discussions of the literature; vertebrates: Brockelman, 1975; Winkler and Walters, 1983; invertebrates: Wilson and Lessells, 1994; Fox and Czesak, 2000). These results suggest that in animals, selection primarily optimizes offspring size, again in accordance with optimality models, rather than fecundity. However, exceptions exist where offspring number, rather than size, is optimized. For instance, in reptiles, although large clutch sizes are ancestral, invariant clutch size with a small number of eggs has evolved independently in some lineages (Kratochvíl and Kubička, 2007; see also Sinervo and Licht, 1991; Goodman, 2006), and egg size can vary in such lineages (Shanbhag et al., 2003). The evolutionary advantages of invariant clutch size are not well-understood.

\section{LIFE HISTORY AND MORPHOLOGICAL CONSTRAINTS ON EGG SIZE AND NUMBER}

As in the case of plants, morphological and other constraints may limit fecundity or offspring size in animals. Our analysis focuses on data rich groups (reptiles and birds).

\section{Parental Care}

Parental care complicates evolutionary interpretation of the offspring size-number tradeoff in animal reproductive strategies, because ultimately it is the overall parental investment that matters. Lack (1954) hypothesized that female birds lay as many eggs as they can provide parental care for, but studies using experimental egg addition have shown that many birds produce fewer eggs than predicted by Lack's hypothesis (Linden and Møller, 1989; Vander Werf, 1992; Monaghan and Nager, 1997). This is not due to an inability to produce more eggs, since many birds with invariant clutch sizes in the wild can be induced into laying additional eggs by experimental egg removal (Parsons, 1976; Monaghan et al., 1995, 1998). Instead, many studies have indicated a tradeoff between current and future reproduction, since rearing a large clutch may deteriorate the parent's condition and reduce survival (e.g., in European blue tits, Cyanistes caeruleus, Nur, 1984; in Great tits Parus major, Visser and Lessells, 2001) or reproductive performance in the future (Linden and Møller, 1989; Monaghan and Nager, 1997). Another factor often neglected in egg-addition studies is the costs of producing these additional eggs (as opposed to rearing the fledglings). For example, in black-backed gulls (Larus fuscus), inducing females to lay one additional egg (which replaces an experimentally removed one) decreases female condition and reduces their capacity of successfully rearing offspring (Monaghan et al., 1998; Nager et al., 2001). Finally, large clutch sizes may also lead to reduced offspring fitness (Monaghan et al., 1995; Nager et al., 2000).

Offspring number optimization takes precedence over size optimization most evidently in oviparous animals where mothers regulate the number of offspring based on an assessment of available resources, although it is unclear why mothers do not regulate egg size instead. Optimization of offspring numbers is often achieved through infanticide or selective abortion, and such a paradox (reduction in fecundity) can be explained to an extent in terms of resource availability. The most striking examples of infanticide are the birds and mammals that starve the weakest offspring to death when resources become limited after egg laying (Lack, 1954; Ricklefs, 1965; Klopfer and Klopfer, 1973), presumably to endow more resources to the remaining offspring that have high parental fitness costs.

Correlational data from diverse invertebrate and poikilothermic (cold-blooded vertebrate) taxa show that parental care tends to be associated with increased egg-size (Shine, 1978), and this pattern has been confirmed by several phylogenetically controlled comparative studies in diverse lineages-fishes (e.g., Gross and Sargent, 1985, see Kolm and Ahnesjö, 2005 for a review), salamanders (Nussbaum, 1987) and frogs (Summers et al., 2006), although Gilbert and Manica (2015) did not find such a pattern in insects.

Several explanations have been proposed to explain the relationship between parental care and egg size-readers are referred to Kolm and Ahnesjö (2005) and Shine (1989) for reviews of these hypotheses. Of relevance here is the idea that parental care and egg-size co-evolve (Nussbaum and Schultz, 1989) - i.e., a change in egg size leads to a change in parental care and vice-versa. For instance, loss of parental care in a lineage can place a constraint on egg-size, or gain of parental care may allow 
larger egg sizes. Summers et al. (2006) found that the evolution of large egg size usually precedes the evolution of parental care in frogs, suggesting that egg size constrains parental care, or that large eggs require parental care. Further comparative analyses are needed to test the intriguing scenario of co-evolution between egg size and parental care in other taxa.

\section{Morphological Constraints on Offspring Size}

We have previously discussed how body size is strongly associated with offspring size and number. Here, we discuss other morphological constraints on offspring size. Such constraints are relatively well characterized in reptiles. In turtles, pelvic girdle aperture, which is a function of maternal body size, places an upper limit on egg size (Congdon and Gibbons, 1987). Pelvic girdle aperture has also been suggested to limit neonate size in primates (Leutenegger, 1979). In Calotes versicolor, an agamid lizard, pelvic aperture itself does not vary with female size, but limits egg width, whereas egg volume varies adaptively with length (Shanbhag et al., 2000). Sinervo and Licht (1991) found that larger eggs of side-blotched lizards (Uta stansburiana) were more likely to be oviducally bound or burst upon oviposition. In the crustacean Daphnia, brood pouch size limits offspring size, even if large offspring size is favorable under certain environmental conditions (Robertson, 1988). In many lepidopteran insects, egg size decreases with age (Murphy et al., 1983; Karlsson and Wiklund, 1984, p. 84; Yanagi and Miyatake, 2002; Giron and Casas, 2003), suggesting that it is constrained by impoverished resources of aging mothers (the partial resource depletion hypothesis: Wiklund and Karlsson, 1984). Minimum egg size is also likely to be constrained by fitness attributes such as the ability of hatchlings to capture prey (Stewart et al., 1991) or to begin feeding.

\section{Relationship between Offspring Size and Fitness}

Larger egg size almost always translates to larger hatchling size (e.g., Birkhead and Nettleship, 1982; Braby, 1994; Ernsting and Isaaks, 1997; Einum and Fleming, 1999, see also Fox and Czesak, 2000). Although, offspring fitness is extremely difficult to quantify, a large number of studies have reported a positive correlation between offspring size and fitness proxies (e.g., survival in birds: Richdale, 1963; Perrins, 1965; survival in fish: see Reznick, 1991; Sogard, 1997; survival and growth in bryozoans: Marshall et al., 2003; survival and growth in marine benthic invertebrates: see Moran, 1999; survival and growth in frogs: Dziminski and Roberts, 2006; hatchling sprint speed in lizards: Sinervo, 1990; hatchability of insect eggs: Fischer and Fiedler, 2001; competitive ability in insects: Azevedo et al., 1997; starvation resistance in insects: Carlberg, 1984; Solbreck, 1986; Gliwicz and Guisande, 1992; faster development in insects: Fox, 1994, p. 94; see Fox and Czesak, 2000; Krist, 2011 for more examples). Many insects demonstrate adaptive plasticity of egg size, that is, they are able to modulate egg size depending on the quality of their hosts (Nakasuji, 1987; Braby, 1994; Fox et al., $1997,1999)$ or other environmental parameters.
Some studies, especially on butterflies, have failed to find a positive relationship between offspring size and any of the tested fitness proxies (e.g., Wiklund and Persson, 1983; Karlsson and Wiklund, 1984, 1985; Wiklund and Karlsson, 1984; Wiklund et al., 1987). This lack of a significant correlation could possibly be due to a threshold value of egg size required for offspring survival (Wiklund et al., 1987). It may also be related to the experimental conditions not imposing strong enough constraints or stresses on offspring compared to natural conditions (Fox and Mousseau, 1996). Indeed, Heath et al. (2003) have shown for salmon that although larger egg sizes are selected under natural conditions, captive breeding relaxes this selection, such that fecundity quickly increases over generations.

Conversely, selection may act against large body size. Plausible costs of large size include increased susceptibility to predation or parasitism, reduced agility and longer time to maturation (see Blanckenhorn, 2000). Therefore, the widely-accepted model of offspring fitness increasing monotonically with size may not be universal (Hendry et al., 2001). Aquatic animals provide notable empirical examples of costs of larger size during particular developmental stages (Hendry et al., 2001; Dibattista et al., 2007; Sun et al., 2015).

Physiological constraints on egg size in aquatic organisms has been discussed as an example where larger size may incur fitness costs. Eggs of most aquatic organisms are small (Goncalves et al., 2015), which has been attributed to oxygen limitation (Van Den Berghe and Gross, 1989; Einum et al., 2002). Because eggs of aquatic organisms are usually spherical (Goncalves et al., 2015), the ratio of surface area to volume is smaller for larger eggs, thus larger eggs are more likely to face an oxygen deficit (Einum et al., 2002; Kolm and Ahnesjö, 2005). Although this long-standing hypothesis appears compelling, empirical evidence is lacking (Einum et al., 2002; Goncalves et al., 2015). Thus, the factors that constrain egg size in aquatic animals, and how this constraint influences the size-number tradeoff needs further investigation.

\section{GENETIC CONTROLS ON OFFSPRING SIZE AND FECUNDITY IN ANIMALS: LESSONS FROM DROSOPHILA}

Egg size has generally been shown to have high heritability in animals, for instance, in birds such as the great tit (Parus major; Ojanen et al., 1979) and turkey (Meleagris gallopavo; Nestor et al., 1972 and references therein), as well as lizards (Sinervo and Doughty, 1996). Economically important egg traits in chicken (yolk volume, egg weight) are known to have high heritability (Olsen and Knox, 1940; Shultz, 1953; Zhang et al., 2005). We know little about the genetic control of egg size and number in non-model animal taxa, and most of what we know comes from the common fruit fly Drosophila melanogaster, for which the egg size-number tradeoff is well-known (Mackay et al., 2012; Jha et al., 2015).

The first attempt to understand the genetic regulation of egg size in D. melanogaster was by Warren (1924), who found that egg size varied considerably across mutant lines. Based on data from controlled crosses, he concluded that egg size is 
polygenically controlled by genes on all four chromosomes. Jha et al. (2015) adopted a whole-genome resequencing approach on replicated experimental-evolution lines selected for large and small egg sizes, respectively. Corroborating Warren's findings, Jha and colleagues report that egg size is polygenically controlled by at least 200 genes. Their analyses detected signatures of selection on specific genomic regions linked to egg size, as well as directional selection on known genes, including those involved in regulation of cell size, egg growth and development. They identified 193 candidate genes, and highlight the role of two genes, Plod and Iola, using crosses of mutant lines. RNAi knockdown experiments have previously shown that Plod controls egg length (Lerner et al., 2013). The list of candidate genes identified by Jha and colleagues promises to lay the foundation for further studies that can elucidate the genetic basis of egg-size variation in D. melanogaster. Schwarzkopf et al. (1999) selected D. melanogaster for large and small egg size relative to female body size, and found that egg size responded strongly in both directions. Surprisingly, a negative correlation between absolute egg size and fecundity was observed in the large-egg selected line but not in the small-selected lines or the control (without selection). There was no genetic correlation between relative egg size and relative fecundity in any selection line, suggesting that there was no negative genetic correlation between egg size and number (a trend indicating similarity with Arabidopsis). However, as the authors discuss, it is possible that such a correlation may be obscured by complex phenotypic interactions with other life history traits. Furthermore, total reproductive allocation decreased in the small-egg selected line, which suggests that resource allocation to reproduction may be dependent on offspring size. The intriguing results in this study further underscore the potential of experimental evolution to understand genetic controls of offspring size variation.

\section{ENVIRONMENTAL FACTORS INFLUENCING OFFSPRING SIZE WITHIN SPECIES}

Differences in environments can select for variation in offspring size, and the fitness difference between larger and smaller offspring is generally greatest in poorest quality or stressful environments (see Fox and Czesak, 2000). Generally, more stressful environments tend to select for larger offspring size in animals. We first discuss selection pressures exerted by components of the abiotic environment. In arthropods, these include soil depth (Carrière et al., 1997), temperature (Perrin, 1988; Avelar, 1993; Azevedo et al., 1996; Crill et al., 1996; Ernsting and Isaaks, 1997, 2000; Fischer et al., 2003) and photoperiod (Ernsting and Isaaks, 2000). A given environmental variable can have a positive or negative correlation with offspring size in different species. For instance, populations of Sceleporus lizards show a pattern of increased egg size with decreasing temperature, which manifests across both altitudinal and latitudinal gradients (Sinervo, 1990). Similar results were reported in various other species, including Drosophila (Azevedo et al., 1997), where wild and experimental laboratory populations evolving at lower temperatures produced larger eggs. The same pattern has been repeatedly found in various other species, while a converse pattern of larger eggs at higher temperatures has also been reported, albeit less commonly (see Fox and Czesak, 2000). One argument for the prevalence of larger eggs at lower temperatures is that survival over longer developmental periods at lower temperature necessitates more resources (Kolding and Fenchel, 1981; Yampolsky and Scheiner, 1996). Thus far, experimental evidence for the adaptive significance of variation in egg size across different conditions is limited, possibly because experimental conditions do not adequately mimic the complexity of natural environments. Other biotic factors that strongly select for large or small differential offspring size include food quality (e.g., Brody and Lawlor, 1984; Braby, 1994), competition (e.g., Parker and Begon, 1986), inbreeding (e.g., Duthie et al., 2016), limited dispersal (e.g., Kuijper and Johnstone, 2012) and predation (e.g., Kerfoot, 1974; Ernsting and Isaaks, 1997) (see also Table 2 in Rollinson and Rowe, 2016). In particular, increased competition generally selects for larger offspring size, while sizedependent predation may select for either smaller or larger offspring.

\section{CONCLUSION: A SYNTHETIC VIEW OF ANIMAL AND PLANT REPRODUCTIVE STRATEGIES}

Seeds (in plants) and eggs (in animals) have evolved independently, but serve the same function. Consequently, strikingly similar adaptive strategies have emerged in parallel in plants and animals. The current review brings together theoretical and empirical work on plants and animals, at both micro- and macro-evolutionary scales, focusing on one of the most universal evolutionary tradeoffs. Although the diversity in reproductive strategies is almost infinite, it is striking that limitation of resources available for reproduction is ubiquitous and selection has resulted in surprisingly similar solutions in animals and plants. In particular, we identify the following similarities, which enable an all-encompassing view of reproductive strategies in plants and animals alike:

a. Offspring size is generally less variable than offspring number, suggesting that optimization of size is generally under stronger selection than optimization of numbers. Costs of increasing offspring size are likely greater than increasing offspring number in both plants and animals.

b. Maternal controls (vis-à-vis zygotic controls) over offspring size optimization is expected to be (i) weaker in animals (and a few seed plants) that show parental care and (ii) stronger when there is competition (rivalry) between offspring (siblings and non-siblings). When it is not possible to provide sufficient resources for all developing offspring, mothers can selectively sacrifice inferior offspring to ensure optimal resources for the remaining. Plants can achieve this through embryo abortion, while animals can starve the weakest offspring.

c. Increasing structural complexity and body size are correlated with increasing offspring size and a concomitant reduction in fecundity. Offspring size is limited by morphological 
constraints, for instance pelvic girdle aperture in animals and growth form (plant form) in plants.

d. During later reproductive stages, offspring size appears to be limited by depletion of maternal resources, due to either aging of the parent or seasonal changes. Sub-optimal environments generally increase the variance of offspring size.

Despite these similarities, there are also significant idiosyncratic differences between reproductive strategies of animals and plants, which demand further exploration.

a. In animals, harsher environmental conditions generally lead to increased offspring size (at the cost of reduced offspring numbers). In contrast, plants in harsh environments tend to produce a large number of small seeds (although not always).

b. Vegetative reproduction in plants will not only create clones (as they do in asexually reproducing animals) but also severely restrict dispersal, intensify local competition for resources and ultimately reduce offspring fitness. The notion of maternal controls over resource allocation to reproduction may not hold in plants that propagate vegetatively (especially those with dormant, physiologically united subterranean structures), since the distinction between parent and offspring is blurred.

c. Some perennial (iteroparous) plants have extraordinarily longer life spans than most animals. As a result, parentoffspring conflict could be extended for many generations, beyond mere maternal and zygotic competition for resources during zygote development. Long life spans could also make perennial plant reproductive traits more plastic than those of animals.

While there is overwhelming experimental evidence supporting the assumption that offspring born from larger eggs

\section{REFERENCES}

Aarssen, L. W. (1995). Hypotheses for the evolution of apical dominance in plants: implications for the interpretation of overcompensation. Oikos 74, 149-156. doi: $10.2307 / 3545684$

Aarssen, L. W. (2015). Body size and fitness in plants: revisiting the selection consequences of competition. Perspect. Plant Ecol. Evol. Syst. 17, 236-242. doi: $10.1016 /$ j.ppees.2015.02.004

Aarssen, L. W., and Jordan, C. Y. (2001). Between-species patterns of covariation in plant size, seed size and fecundity in monocarpic herbs. Ecoscience 8, 471-477. doi: 10.1080/11956860.2001.11682677

Adamski, N. M., Anastasiou, E., Eriksson, S., O’Neill, C. M., and Lenhard, M. (2009). Local maternal control of seed size by KLUH/CYP78A5dependent growth signaling. Proc. Nat. Acad. Sci. U.S.A. 106, 20115-20120. doi: 10.1073/pnas.090702410

Ali, Q., Ashraf, M., Anwar, F., and Al-Qurainy, F. (2012). Trehalose-induced changes in seed oil composition and antioxidant potential of maize grown under drought stress. J. Am. Oil Chemists Soc. 89, 1485-1493. doi: $10.1007 / \mathrm{s} 11746-012-2032-\mathrm{z}$

Andresen, E., and Levey, D. J. (2004). Effects of dung and seed size on secondary dispersal, seed predation, and seedling establishment of rain forest trees. Oecologia 139, 45-54. doi: 10.1007/s00442-0031480-4

Avelar, T. (1993). Egg size in Drosophila: Standard Unit of investment of variable response to environment? The effect of temperature. J. Insect Physiol. 39, 283-289. doi: 10.1016/0022-1910(93)90058-Y or seeds have higher fitness, there are various scenarios where this assumption may not hold true due to both intrinsic (genetic) and extrinsic (environmental) regulatory factors. We still do not understand the genetic architecture of parent-offspring conflict during instances of selective abortion in both animals and plants. Exciting mechanistic and field investigations of offspring sizenumber tradeoffs under sub-optimal environmental conditions are anticipated ahead.

\section{AUTHOR CONTRIBUTIONS}

UK proposed the review idea to KGSD. KGSD synthesized and analyzed the literature on plant reproductive strategies and optimization models, designed the illustrations, and developed arguments concerning genetic controls on offspring size. UK analyzed the animal literature and conceived the syntheses. Both the authors contributed to the manuscript writing process.

\section{FUNDING}

This work was supported by the grant BT/PR12720/ COE/34/21/2015 (Project A3) from the Department of Biotechnology, Government of India.

\section{ACKNOWLEDGMENTS}

We are grateful to Prof. R. Uma Shaanker (University of Agricultural Sciences -GKVK, Bengaluru) and the three reviewers from the Frontiers review panel, whose constructive comments and insights improved the manuscript significantly.

Azevedo, R. B., French, V., and Partridge, L. (1996). Thermal evolution of egg size in Drosophila melanogaster. Evolution 50, 2338-2345. doi: 10.2307/24 10702

Azevedo, R. B., Partridge, L., and French, V. (1997). Life-history consequences of egg size in Drosophila melanogaster. Am. Nat. 150, 250-282. doi: $10.1086 / 286065$

Baroux, C., Autran, D., Gillmor, C. S., Grimanelli, D., and Grossniklaus, U. (2008). "The maternal to zygotic transition in animals and plants," in Cold Spring Harbor Symposia on Quantitative Biology, Vol. 73 (New York, NY).

Baroux, C., Spillane, C., and Grossniklaus, U. (2002). Evolutionary origins of the endosperm in flowering plants. Genome Biol. 3, 1026-1041. doi: 10.1186/gb-2002-3-9-reviews1026

Baskin, C. C., and Baskin, J. M. (1998). Seeds: Ecology, Biogeography, and Evolution of Dormancy and Germination. San Diego, CA: Elsevier.

Bateman, R. M., and DiMichele, W. A. (1994). Heterospory: the most iterative key innovation in the evolutionary history of the plant kingdom. Biol. Rev. 69, 345-417. doi: 10.1111/j.1469-185X.1994.tb01276.x

Beaulieu, J. M., Moles, A. T., Leitch, I. J., Bennett, M. D., Dickie, J. B., and Knight, C. A. (2007). Correlated evolution of genome size and seed mass. New Phytol. 173, 422-437. doi: 10.1111/j.1469-8137.2006.01919.x

Ben-Hur, E., and Kadmon, R. (2015). An experimental test of the relationship between seed size and competitive ability in annual plants. Oikos 124, 1346-1353. doi: 10.1111/oik.02111

Ben-Hur, E., Fragman-Sapir, O., Hadas, R., Singer, A., and Kadmon, R. (2012). Functional trade-offs increase species diversity in experimental plant communities. Ecol. Lett. 15, 1276-1282. doi: 10.1111/j.1461-0248.2012.01850.x 
Bernardo, J. (1996). The particular maternal effect of propagule size, especially egg size: patterns, models, quality of evidence and interpretations. Integr. Comp. Biol. 36, 216-236. doi: 10.1093/icb/36.2.216

Berrigan, D. (1991). The allometry of egg size and number in insects. Oikos 60, 313-321. doi: 10.2307/3545073

Bewley, J. D., and Black, M. (1994). Seeds. New York, NY: Springer.

Birkhead, T., and Nettleship, D. (1982). The adaptive significance of egg size and laying date in Thick-billed Murres Uria lomvia. Ecol. 63, 300-306. doi: $10.2307 / 1938946$

Blanckenhorn, W. U. (2000). The Evolution of Body Size: what Keeps Organisms Small? Q. Rev. Biol. 75, 385-407. doi: 10.1086/393620

Bommert, P., Nagasawa, N. S., and Jackson, D. (2013). Quantitative variation in maize kernel row number is controlled by the FASCIATED EAR2 locus. Nat. Gen. 45, 334-337. doi: 10.1038/ng.2534

Braby, M. F. (1994). The significance of egg size variation in butterflies in relation to hostplant quality. Oikos 71, 119-129. doi: 10.2307/3546179

Bradshaw, A. D. (1972). Some of the evolutionary consequences of being a plant. Evol. Biol. 5, 25-47. doi: 10.1007/978-1-4757-0256-9_2

Bremner, P. M., Eckersall, R. N., and Scott, R. K. (1963). The relative importance of embryo size and endosperm size in causing the effects associated with seed size in wheat. J. Agri. Sci. 61, 139-145. doi: 10.1017/S00218596000 13800

Brockelman, W. Y. (1975). Competition, the fitness of offspring, and optimal clutch size. Am. Nat. 109, 677-699. doi: 10.1086/283037

Brody, M. S., and Lawlor, L. R. (1984). Adaptive variation in offspring size in the terrestrial isopod, Armadillidium vulgare. Oecologia 61, 55-59. doi: 10.1007/BF00379089

Burd, M., Ashman, T. L., Campbell, D. R., Dudash, M. R., Johnston, M. O., Knight, T. M., et al. (2009). Ovule number per flower in a world of unpredictable pollination. Am. J. Bot. 96, 1159-1167. doi: 10.3732/ajb.0800183

Canales, C., Bhatt, A. M., Scott, R., and Dickinson, H. (2002). EXS, a putative LRR receptor kinase, regulates male germline cell number and tapetal identity and promotes seed development in Arabidopsis. Curr. Biol. 12, 1718-1727. doi: 10.1016/S0960-9822(02)01151-X

Carlberg, U. (1984). Variations in the egg-size of Extatosoma tiaratum (MacLeay) (Insecta: Phasmida). Zoologischer Anzeiger 212, 61-67.

Carrière, Y., and Roff, D. A. (1995). The evolution of offspring size and number: a test of the Smith-Fretwell model in three species of crickets. Oecologia 102, 389-396. doi: 10.1007/BF00329806

Carrière, Y., Masaki, S., and Roff, D. A. (1997). The coadaptation of female morphology and offspring size: a comparative analysis in crickets. Oecologia 110, 197-204. doi: 10.1007/s004420050150

Cavers, P. B., and Steel, M. G. (1984). Patterns of change in seed weight over time on individual plants. Am. Nat. 124, 324-335. doi: 10.1086/284276

Charnov, E. L. (1976). Optimal foraging, the marginal value theorem. Theor. Populat. Biol. 9, 129-136. doi: 10.1016/0040-5809(76)90040-X

Clarke, A. (1993). Reproductive Trade-Offs in Caridean Shrimps. Func. Ecol. 7, 411-419. doi: 10.2307/2390028

Cohen, D. (1966). Optimizing reproduction in a randomly varying environment. J. Theor. Biol. 12, 119-129. doi: 10.1016/0022-5193(66)90188-3

Congdon, J. D., and Gibbons, J. W. (1987). Morphological constraint on egg size: a challenge to optimal egg size theory? Proc. Nat. Acad. Sci. U.S.A. 84, 4145-4147. doi: $10.1073 /$ pnas. 84.12 .4145

Coomes, D. A., and Grubb, P. J. (2003). Colonization, tolerance, competition and seed-size variation within functional groups. Trends Ecol. Evol. 18, 283-291. doi: 10.1016/S0169-5347(03)00072-7

Crepet, W. L., Friis, E. M., Nixon, K. C., Lack, A. J., and Jarzembowski, E. A. (1991). Fossil evidence for the evolution of biotic pollination [and discussion]. Phil. Trans. Roy.Soc. Lond. B Biol. Sci. 333, 187-195. doi: 10.1098/rstb.1991.0067

Crill, W. D., Huey, R. B., and Gilchrist, G. W. (1996). Within- and betweengeneration effects of temperature on the morphology and physiology of Drosophila melanogaster. Evolution 50, 1205-1218. doi: 10.2307/ 2410661

Damuth, J. D. (1998). Population ecology: common rules for animals and plants. Nature 395, 115-116. doi: 10.1038/25843

Darwin, C. (1859). On the origin of species. London. John Murray.

Daws, M. I., Ballard, C., Mullins, C. E., Garwood, N. C., Murray, B., Pearson, T. R. H., et al. (2007). Allometric relationships between seed mass and seedling characteristics reveal trade-offs for neotropical gap-dependent species. Oecologia 154, 445-454. doi: 10.1007/s00442-007-0848-2

Dibattista, J. D., Feldheim, K. A., Gruber, S. H., and Hendry, A. P. (2007). When bigger is not better: selection against large size, high condition and fast growth in juvenile lemon sharks. J. Evol. Biol. 20, 201-212. doi: $10.1111 /$ j.1420-9101.2006.01210.x

Duthie, A. B., Lee, A. M., and Reid, J. M. (2016). Inbreeding parents should invest more resources in fewer offspring. Proc. R. Soc. B 283:20161845. doi: $10.1098 / \mathrm{rspb} .2016 .1845$

Dziminski, M. A., and Roberts, J. D. (2006). Fitness consequences of variable maternal provisioning in quacking frogs (Crinia georgiana). J. Evol. Biol. 19, 144-155. doi: 10.1111/j.1420-9101.2005.00978.x

Einum, S., and Fleming, I. A. (1999). Maternal effects of egg size in brown trout (Salmo trutta): norms of reaction to environmental quality. Proc. Roy. Soc. B 266, 2095-2100. doi: 10.1098/rspb.1999.0893

Einum, S., Hendry, A. P., and Fleming, I. A. (2002). Egg-size evolution in aquatic environments: does oxygen availability constrain size? Proc. R. Soc. Lond. B Biol. Sci. 269, 2325-2330. doi: 10.1098/rspb.2002.2150

Einum, S., Kinnison, M. T., and Hendry Andrew, P. (2004). "Evolution of egg size and number," in Evolution Illuminated: Salmon and their Relatives, eds A. P. Hendry and S. C. Stearns (New York, NY: Oxford University Press), 126-153.

Elmqvist, T., and Cox, P. A. (1996). The evolution of vivipary in flowering plants. Oikos 77, 3-9. doi: 10.2307/3545579

Endress, P. K. (2001). Origins of flower morphology. J. Exp. Zool. 291, 105-115. doi: $10.1002 /$ jez. 1063

Ernsting, G., and Isaaks, A. (2000). Ectotherms, temperature, and trade-offs: size and number of eggs in a carabid beetle. Am. Nat. 155, 804-813. doi: $10.1086 / 303361$

Ernsting, G., and Isaaks, J. (1997). Effects of temperature and season on egg size, hatchling size and adult size in Notiophilus biguttatus. Ecol. Entomol. 22, 32-40. doi: 10.1046/j.1365-2311.1997.00040.x

Fang, W., Wang, Z., Cui, R., Li, J., and Li, Y. (2012). Maternal control of seed size by EOD3/CYP78A6 in Arabidopsis thaliana: EOD3/CYP78A6 and CYP78A9 and seed size. Plant J. 70, 929-939. doi: 10.1111/j.1365-313X.2012.04907.x

Farnsworth, E. J., and Ellison, A. M. (1997). Global patterns of predispersal propagule predation in mangrove Forests1. Biotropica 29, 318-330. doi: 10.1111/j.1744-7429.1997.tb00433.x

Finch-Savage, W. E., and Leubner-Metzger, G. (2006). Seed dormancy and the control of germination: tansley review. New Phytol. 171, 501-523. doi: 10.1111/j.1469-8137.2006.01787.x

Fischer, K., and Fiedler, K. (2001). Egg weight variation in the butterfly Lycaena hippothoe: more small or fewer large eggs? Population Ecol. 43, 105-109. doi: 10.1007/pl00012009

Fischer, K., Brakefield, P. M., and Zwaan, B. J. (2003). Plasticity in butterfly egg size: why larger offspring at lower temperatures? Ecology 84, 3138-3147. doi: $10.1890 / 02-0733$

Fleming, I. A., and Gross, M. R. (1990). Latitudinal clines: a trade-off between egg number and size in Pacific salmon. Ecology 71, 2-11. doi: 10.2307/1940241

Forbis, T. A., Floyd, S. K., and Queiroz, A., de (2002). The evolution of embryo size in angiosperms and other seed plants: implications for the evolution of seed dormancy. Evolution 56, 2112-2125. doi: 10.1111/j.0014-3820.2002.tb00137.x

Fox, C. W. (1994). The influence of egg size on offspring performance in the seed beetle, Callosobruchus maculatus. Oikos 71, 321-325. doi: 10.2307/3546280

Fox, C. W., and Czesak, M. E. (2000). Evolutionary ecology of progeny size in arthropods. Ann. Rev. Entomol. 45, 341-369. doi: 10.1146/annurev.ento.45.1.341

Fox, C. W., and Mousseau, T. A. (1996). Larval host plant affects fitness consequences of egg size variation in the seed beetle Stator limbatus. Oecologia 107, 541-548. doi: 10.1007/BF00333946

Fox, C. W., Czesak, M. E., Mousseau, T. A., and Roff, D. A. (1999). The evolutionary genetics of an adaptive maternal effect: egg size plasticity in a seed beetle. Evolution 53, 552-560. doi: 10.2307/2640791

Fox, C. W., Thakar, M. S., and Mousseau, T. A. (1997). Egg size plasticity in a seed beetle: an adaptive maternal effect. Am. Natl. 149, 149-163. doi: 10.1086/285983

Friedman, W. E. (1995). Organismal duplication, inclusive fitness theory, and altruism: understanding the evolution of endosperm and the angiosperm reproductive syndrome. Proc. Natl. Acad. Sci. U.S.A. 92, 3913-3917. doi: 10.1073/pnas.92.9.3913 
Friedman, W. E., and Williams, J. H. (2003). Modularity of the angiosperm female gametophyte and its bearing on the early evolution of endosperm in flowering plants. Evolution 57, 216-230. doi: 10.1111/j.0014-3820.2003.tb00257.x

Ganeshaiah, K. N., and Uma Shaanker, R. (1988). Seed abortion in wind-dispersed pods of Dalbergia sissoo: maternal regulation or sibling rivalry? Oecologia 77, 135-139. doi: 10.1007/BF00380936

Ganeshaiah, K. N., and Uma Shaanker, R. (1991). Seed size optimization in a wind dispersed tree butea monosperma: a trade-off between seedling establishment and pod dispersal efficiency. Oikos 60, 3-6. doi: 10.2307/3544984

Garcia, D. (2003). Arabidopsis haiku mutants reveal new controls of seed size by endosperm. Plant Physiol. 131, 1661-1670. doi: 10.1104/pp.102.018762

Garcia, D. (2005). Maternal control of integument cell elongation and zygotic control of endosperm growth are coordinated to determine seed size in arabidopsis. Plant Cell Online 17, 52-60. doi: 10.1105/tpc.104.027136

García-Barros, E. (2000a). Body size, egg size, and their interspecific relationships with ecological and life history traits in butterflies (Lepidoptera: Papilionoidea, Hesperioidea). Biol. J. Lin. Soc. 70, 251-284. doi: 10.1111/j.1095-8312.2000.tb00210.x

García-Barros, E. (2000b). Egg size in butterflies (Lepidoptera: Papilionoidea and Hesperiidae): a summary of data. J. Res. Lepid. 35, 90-136.

Gegas, V. C., Nazari, A., Griffiths, S., Simmonds, J., Fish, L., Orford, S., et al. (2010). A genetic framework for grain size and shape variation in wheat. Plant Cell 22, 1046-1056. doi: $10.1105 /$ tpc. 110.074153

Germain, R. M., and Gilbert, B. (2014). Hidden responses to environmental variation: maternal effects reveal species niche dimensions. Ecol. Lett. 17, 662-669. doi: 10.1111/ele.12267

Gilbert, J. D. J., and Manica, A. (2015). The evolution of parental care in insects: A test of current hypotheses. Evol. Int. J. Organic Evol. 69, 1255-1270. doi: $10.1111 /$ evo.12656

Giron, D., and Casas, J. (2003). Mothers reduce egg provisioning with age. Ecol. Lett. 6, 273-277. doi: 10.1046/j.1461-0248.2003.00429.x

Gliwicz, Z. M., and Guisande, C. (1992). Family planning in daphnia: resistance to starvation in offspring born to mothers grown at different food levels. Oecologia 91, 463-467. doi: 10.1007/BF00650317

Gnan, S., Priest, A., and Kover, P. X. (2014). The genetic basis of natural variation in seed size and seed number and their trade-off using Arabidopsis thaliana MAGIC lines. Genetics 198, 1751-1758. doi: 10.1534/genetics.114.170746

Godfray, H. C. J., Parker, G. A., and Haig, D. (1991). Clutch size, fecundity and parent-offspring conflict [and discussion]. Philos. Trans. R. Soc. Lond. Ser. B Biol. Sci. 332:67. doi: 10.1098/rstb.1991.0034

Gommers, C. M. M., Visser, E. J. W., Onge, K. R. S., Voesenek, L. A. C. J., and Pierik, R. (2013). Shade tolerance: when growing tall is not an option. Trends Plant Sci. 18, 65-71. doi: 10.1016/j.tplants.2012.09.008

Goncalves, I. B., Ahnesjö, I., and Kvarnemo, C. (2015). The evolutionary puzzle of egg size, oxygenation and parental care in aquatic environments. Proc. R. Soc. B 282:20150690. doi: 10.1098/rspb.2015.0690

Goodman, B. A. (2006). The effects of maternal size on clutch traits in a tropical invariant-clutch lizard, Carlia rubrigularis (Scincidae). Amphibia Reptilia 27, 505-511. doi: 10.1163/156853806778877167

Greene, D. F., and Johnson, E. A. (1994). Estimating the mean annual seed production of trees. Ecology 75, 642-647. doi: 10.2307/1941722

Greenway, C. A., and Harder, L. D. (2007). Variation in ovule and seed size and associated size-number tradeoffs in angiosperms. Am. J. Bot. 94, 840-846. doi: $10.3732 / a j b .94 .5 .840$

Gremer, J. R., and Venable, D. L. (2014). Bet hedging in desert winter annual plants: optimal germination strategies in a variable environment. Ecol. Lett. 17, 380-387. doi: 10.1111/ele.12241

Gross, M. R., and Sargent, R. C. (1985). The evolution of male and female parental care in fishes. Am. Zool. 25, 807-822. doi: 10.1093/icb/25.3.807

Guntrip, J., Sibly, R. M., and Smith, R. H. (1997). Controlling resource acquisition to reveal a life history trade-off: egg mass and clutch size in an iteroparous seed predator, Prostephanus truncatus. Ecol. Entomol. 22, 264-270. doi: 10.1046/j.1365-2311.1997.00076.x

Haig, D. (1990). Brood reduction and optimal parental investment when offspring differ in quality. Am. Nat. 136, 549-556. doi: 10.1086/285113

Halford, N. G., Curtis, T. Y., Chen, Z., and Huang, J. (2015). Effects of abiotic stress and crop management on cereal grain composition: implications for food quality and safety. J. Exp. Bot. 66, 1145-1156. doi: 10.1093/jxb/eru473
Halpern, S. L. (2005). Sources and consequences of seed size variation in Lupinus perennis (Fabaceae): adaptive and non-adaptive hypotheses. Am. J. Bot. 92, 205-213. doi: 10.3732/ajb.92.2.205

Harper, J. L. (1967). A Darwinian approach to plant ecology. J. Applied Ecol. 55, $247-270$.

Harper, J. L., and Ogden, J. (1970). The reproductive strategy of higher plants: I. The concept of strategy with special reference to Senecio vulgaris L. J. Ecol. 58, 681-698. doi: 10.2307/2258529

Harper, J. L., Lovell, P. H., and Moore, K. G. (1970). The shapes and sizes of seeds. Annu. Rev. Ecol. Systemat. 1, 327-356. doi: 10.1146/annurev.es.01.110170.001551

Heath, D. D., Heath, J. W., Bryden, C. A., Johnson, R. M., and Fox, C. W. (2003). Rapid evolution of egg size in captive salmon. Science 299, 1738-1740. doi: $10.1126 /$ science. 1079707

Hegde, S. G., Lokesha, R., Ganeshaiah, K. N., and Uma Shaanker, R.(1991). Seed size distribution in plants: an explanation based on fractal geometry. Oikos 62, 100-101. doi: $10.2307 / 3545455$

Hendry, A. P., Day, T., and Cooper, A. B. (2001). Optimal size and number of propagules: allowance for discrete stages and effects of maternal size on reproductive output and offspring fitness. Am. Natl. 157, 387-407. doi: $10.1086 / 319316$

Herridge, R. P., Day, R. C., Baldwin, S., and Macknight, R. C. (2011). Rapid analysis of seed size in Arabidopsis for mutant and QTL discovery. Plant Methods 7:3. doi: 10.1186/1746-4811-7-3

Hester, F. J. (1964). Effects of food supply on fecundity in the female guppy, Lebistes reticulatus (Peters). J. Fisheries Board Can. 21, 757-764. doi: 10.1139/f64-068

Hikosaka, K., Kinugasa, T., Oikawa, S., Onoda, Y., and Hirose, T. (2011). Effects of elevated $\mathrm{CO}_{2}$ concentration on seed production in $\mathrm{C} 3$ annual plants. J. Exp. Bot. 62, 1523-1530. doi: 10.1093/jxb/erq401

Hill, J. P., Edwards, W., and Franks, P. J. (2012). Size is not everything for desiccation-sensitive seeds. J. Ecol. 100, 1131-1140. doi: 10.1111/j.1365-2745.2012.02005.x

Honěk, A. (1993). Intraspecific variation in body size and fecundity in insects: a general relationship. Oikos 66, 483-492. doi: 10.2307/3544943

Huang, R., Jiang, L., Zheng, J., Wang, T., Wang, H., Huang, Y., et al. (2013). Genetic bases of rice grain shape: so many genes, so little known. Trends Plant Sci. 18, 218-226. doi: 10.1016/j.tplants.2012.11.001

Irwin, D. L., and Aarssen, L. W. (1996). Testing for cost of apical dominance in vegetation: a field study of three species. Ann. Botanici Fenn. 33, 123-128.

Jablonski, L. M., Wang, X., and Curtis, P. S. (2002). Plant reproduction under elevated $\mathrm{CO}_{2}$ conditions: a meta-analysis of reports on 79 crop and wild species. New Phytol. 156, 9-26. doi: 10.1046/j.1469-8137.2002. 00494.x

Jakobsson, A., and Eriksson, O. (2000). A comparative study of seed number, seed size, seedling size and recruitment in grassland plants. Oikos 88, 494-502. doi: $10.1034 / \mathrm{j} .1600-0706.2000 .880304 . x$

Janzen, D. H. (1969). Seed-eaters versus seed size, number, toxicity and dispersal. Evolution 23, 1-27. doi: 10.2307/2406478

Jha, A. R., Miles, C. M., Lippert, N. R., Brown, C. D., White, K. P., and Kreitman, M. (2015). Whole genome resequencing of experimental populations reveals polygenic basis of egg size variation in Drosophila melanogaster. Mol. Biol. Evol. 32, 2616-2632. doi: 10.1093/molbev/msv136

Jofuku, K. D., Omidyar, P. K., Gee, Z., and Okamuro, J. K. (2005). Control of seed mass and seed yield by the floral homeotic gene APETALA2. Proc. Nat. Acad. Sci. U.S.A. 102, 3117-3122. doi: 10.1073/pnas.0409893102

Jordan, P. A., Shelton, P. C., and Allen, D. L. (1967). Numbers, turnover, and social structure of the Isle Royale wolf population. Am Zool. 7, 233-252. doi: $10.1093 / \mathrm{icb} / 7.2 .233$

Jørgensen, C., Auer, S. K., and Reznick, D. N. (2011). A model for optimal offspring size in fish, including live-bearing and parental effects. Am. Natl. 177, 119-135. doi: $10.1086 / 659622$

Kaplan, R. H., and Cooper, W. S. (1984). The evolution of developmental plasticity in reproductive characteristics: an application of the 'adaptive coin-flipping' principle. Am. Nat. 123, 393-410. doi: 10.1086/ 284211

Kärkkäinen, K., Savolainen, O., and Koski, V. (1999). Why do plants abort so many developing seeds: bad offspring or bad maternal genotypes?Evol. Ecol. 13, 305-317. doi: 10.1023/a:1006746900736 
Karlsson, B., and Wiklund, C. (1984). Egg weight variation and lack of correlation between egg weight and offspring fitness in the wall brown butterfly Lasiommata megera. Oikos 43, 376-385. doi: 10.2307/3544156

Karlsson, B., and Wiklund, C. (1985). Egg weight variation in relation to egg mortality and starvation endurance of newly hatched larvae in some satyrid butterflies. Ecol. Entomol. 10, 205-211. doi: 10.1111/j.1365-2311.1985.tb00549.x

Kerfoot, W. C. (1974). Egg-Size Cycle of a Cladoceran. Ecology 55, 1259-1270. doi: $10.2307 / 1935454$

Klopfer, P. H., and Klopfer, M. S. (1973). How come leaders to their posts? the determination of social ranks and roles. Am. Sci. 61, 560-564.

Knight, C. A., and Beaulieu, J. M. (2008). Genome size scaling through phenotype space. Ann. Bot. 101, 759-766. doi: 10.1093/aob/mcm321

Kolding, S., and Fenchel, T. M. (1981). Patterns of reproduction in different populations of five species of the amphipod genus gammarus. Oikos 37, 167-172. doi: $10.2307 / 3544461$

Kolm, N., and Ahnesjö, I. (2005). Do egg size and parental care coevolve in fishes? J. Fish Biol. 66, 1499-1515. doi: 10.1111/j.0022-1112.2005.00777.x

Kolm, N., Goodwin, N. B., Balshine, S., and Reynolds, J. D. (2006a). Life history evolution in cichlids 1: revisiting the evolution of life histories in relation to parental care. J. Evol. Biol. 19, 66-75. doi: 10.1111/j.1420-9101.2005.00984.x

Kolm, N., Goodwin, N. B., Balshine, S., and Reynolds, J. D. (2006b). Life history evolution in cichlids 2: directional evolution of the trade-off between egg number and egg size. J. Evol. Biol. 19, 76-84. doi: 10.1111/j.1420-9101.2005.00987.x

Koornneef, M., Alonso-Blanco, C., and Vreugdenhil, D. (2004). Naturally occurring genetic variation in Arabidopsis thaliana. Annu. Rev. Plant Biol. 55, 141-172. doi: 10.1146/annurev.arplant.55.031903.141605

Kratochvíl, L., and Kubička, L. (2007). Why reduce clutch size to one or two eggs? Reproductive allometries reveal different evolutionary causes of invariant clutch size in lizards. Fun. Ecol. 21, 171-177. doi: $10.1111 / j .1365-2435.2006 .01202 . x$

Krist, M. (2011). Egg size and offspring quality: a meta-analysis in birds. Biol. Rev. Camb. Philos. Soc. 86, 692-716. doi: 10.1111/j.1469-185X.2010.00166.x

Kuijper, B., and Johnstone, R. A. (2012). How dispersal influences parent-offspring conflict over investment. Behav. Ecol. 23, 898-906. doi: 10.1093/beheco/ars054

Lack, D. (1954). The Natural Regulation of Animal Numbers. London: Oxford University Press.

Lack, D. (1968). Ecological Adaptations for Breeding in Birds. London: Methuen and Co.

Lalonde, R. G. (1991). Optimal offspring provisioning when resources are not predictable. Am Nat. 138, 680-686. doi: 10.1086/285242

Larios, E., and Venable, D. L. (2015). Maternal adjustment of offspring provisioning and the consequences for dispersal. Ecology 96, 2771-2780. doi: 10.1890/14-1565.1

Lawlor, L. R. (1976). Parental investment and offspring fitness in the terrestrial isopod Armadillidium vulgare (Latr.) (Crustacea: Oniscoidea). Evolution 30, 775-785. doi: $10.2307 / 2407817$

Leishman, M. R., and Westoby, M. (1994). The role of large seed size in shaded conditions: experimental evidence. Func. Ecol. 8, 205-214. doi: $10.2307 / 2389903$

Leishman, M. R., Wright, I. J., Moles, A. T., and Westoby, M. (2000). The evolutionary ecology of seed size. Seeds Ecol. Regen. Plant Commun. 2, 31-57. doi: $10.1079 / 9780851994321.0031$

Lerner, D. W., McCoy, D., Isabella, A. J., Mahowald, A. P., Gerlach, G. F., Chaudhry, T. A., et al. (2013). A Rab10-dependent mechanism for polarized basement membrane secretion during organ morphogenesis. Developmental Cell 24, 159-168. doi: 10.1016/j.devcel.2012.12.005

Leutenegger, W. (1979). Evolution of litter size in primates. Am. Nat. 114, 525-531. doi: $10.1086 / 283499$

Levin, D. A. (1974). The oil content of seeds: an ecological perspective. Am. Nat. 108, 193-206. doi: 10.1086/282899

Levitan,. D. R. (2000). Optimal egg size in marine invertebrates: theory and phylogenetic analysis of the critical relationship between egg size and development time in echinoids. Am. Natl. 156, 175-192. doi: 10.1086/303376

Li, J., and Berger, F. (2012). Endosperm: food for humankind and fodder for scientific discoveries: tansley review. New Phytol. 195, 290-305. doi: $10.1111 /$ j.1469-8137.2012.04182.x
Li, Y., Beisson, F., Pollard, M., and Ohlrogge, J. (2006). Oil content of Arabidopsis seeds: the influence of seed anatomy, light and plant-to-plant variation. Phytochemistry 67, 904-915. doi: 10.1016/j.phytochem.2006.02.015

Linden, M., and Møller, A. P. (1989). Cost of reproduction and covariation of life history traits in birds. Trends Ecol. Evol. 4, 367-371. doi: 10.1016/0169-5347(89)90101-8

Linkies, A., Graeber, K., Knight, C., and Leubner-Metzger, G. (2010). The evolution of seeds. New Phytol. 186, 817-831. doi: 10.1111/j.1469-8137.2010.03249.x

Lokesha, R., Hegde, S. G., Uma Shaanker, R., and Ganeshaiah, K. N. (1992). Dispersal mode as a selective force in shaping the chemical composition of seeds. Am. Nat. 140, 520-525. doi: 10.1086/285425

Lönnberg, K., and Eriksson, O. (2013). Relationships between intra-specific variation in seed size and recruitment in four species in two contrasting habitats. Plant Biol. 15, 601-606. doi: 10.1111/j.1438-8677.2012.00676.x

Lord, J. M., and Westoby, M. (2012). Accessory costs of seed production and the evolution of angiosperms. Evolution 66, 200-210. doi: $10.1111 / \mathrm{j} .1558-5646.2011 .01425 . \mathrm{x}$

Lorts, C. M., Briggeman, T., and Sang, T. (2008). Evolution of fruit types and seed dispersal: a phylogenetic and ecological snapshot. J. Sys. Evol. 46, 396-404. doi: 10.3724/SP.J.1002.2008.08039

Mackay, T. F. C., Richards, S., Stone, E. A., Barbadilla, A., Ayroles, J. F., Zhu, D., et al. (2012). The Drosophila melanogaster Genetic Reference Panel. Nature 482, 173-178. doi: 10.1038/nature10811

Marañón, T., and Grubb, P. J. (1993). Physiological basis and ecological significance of the seed size and relative growth rate relationship in Mediterranean annuals. Func. Ecol. 7, 591-599.

Marshall, D. J., Bolton, T. F., and Keough, M. J. (2003). Offspring Size Affects the Post-Metamorphic Performance of a Colonial Marine Invertebrate. Ecology 84, 3131-3137. doi: 10.1890/02-0311

Martin, A. C. (1946). The comparative internal morphology of seeds. Am. Midland Nat. 36:513. doi: 10.2307/2421457

McGinley, M. A., and Charnov, E. L. (1988). Multiple resources and the optimal balance between size and number of offspring. Evol. Ecol. 2, 77-84. doi: $10.1007 / \mathrm{BF} 02071590$

McGinley, M. A., Temme, D. H., and Geber, M. A. (1987). Parental investment in offspring in variable environments: theoretical and empirical considerations. Am. Nat. 370-398. doi: 10.1086/284716

Mckee, D., and Ebert, D. (1996). The interactive effects of temperature, food level and maternal phenotype on offspring size in Daphnia magna. Oecologia 107, 189-196. doi: 10.1007/BF00327902

Melser, C., and Klinkhamer, P. G. (2001). Selective seed abortion increases offspring survival in Cynoglossum officinale (Boraginaceae). Am. J. Bot. 88, 1033-1040. doi: 10.2307/2657085

Méndez, M. (1997). Sources of variation in seed mass in Arum italicum. Int. J. Plant Sci. 158, 298-305. doi: 10.1086/297441

Mizukami, Y., and Fischer, R. L. (2000). Plant organ size control: AINTEGUMENTA regulates growth and cell numbers during organogenesis. Proc. Nat. Acad. Sci. U.S.A. 97, 942-947. doi: 10.1073/pnas.97.2.942

Mock, D. W. (2004). More than Kin and Less Than Kind: The Evolution of Family Conflict. Cambridge, MA: Belknap Press of Harvard University Press.

Moles, A. T., Ackerly, D. D., Webb, C. O., Tweddle, J. C., et al. (2005). A brief history of seed size. Science 307, 576-580. doi: 10.1126/science. 1104863

Moles, A. T., and Westoby, M. (2004). Seedling survival and seed size: a synthesis of the literature. J. Ecol. 92, 372-383. doi: 10.1111/j.0022-0477.2004. 00884.x

Monaghan, P., and Nager, R. G. (1997). Why don't birds lay more eggs? Trends Ecol. Evol. 12, 270-274. doi: 10.1016/S0169-5347(97)01094-X

Monaghan, P., Bolton, M., and Houston, D. (1995). Egg production constraints and the evolution of avian clutch size. Proc. Roy. Soc. B. Biol Sci. 259, 189-191. doi: $10.1098 /$ rspb.1995.0027

Monaghan, P., Nager, R., and Houston, D. (1998). The price of eggs: increased investment in egg production reduces the offspring rearing capacity of parents. Proc. Roy. Soc. B. Biol Sci. 265, 1731-1735. doi: 10.1098/rspb.19 98.0495

Moran, A. L. (1999). Size and Performance of Juvenile Marine Invertebrates: potential Contrasts between Intertidal and Subtidal Benthic Habitats. Am. Zool. 39, 304-312. doi: 10.1093/icb/39.2.304 
Muller-Landau, H. C. (2010). The tolerance-fecundity trade-off and the maintenance of diversity in seed size. Proc. Natl. Acad. Sci. U.S.A. 107, 4242-4247. doi: 10.1073/pnas.0911637107

Murphy, D. D., Launer, A. E., and Ehrlich, P. R. (1983). The role of adult feeding in egg production and population dynamics of the checkerspot butterfly Euphydryas editha. Oecologia 56, 257-263. doi: 10.1007/BF00379699

Naber, A. C., and Aarssen, L. W. (1998). Effects of shoot apex removal and fruit herbivory on branching, biomass and reproduction in Verbascum thapsus (Scrophulariaceae). Am. Midland. Nat. 140, 42-54. doi: 10.1674/00030031(1998)140[0042:EOSARA]2.0.CO;2

Nager, R. G., Monaghan, P., and Houston, D. C. (2000). Within-clutch tradeoffs between the number and quality of eggs: experimental manipulations in gulls. Ecology 81, 1339-1350. doi: 10.1890/0012-9658(2000)081[1339:WCTOBT]2.0. $\mathrm{CO} ; 2$

Nager, R. G., Monaghan, P., and Houston, D. C. (2001). The cost of egg production: increased egg production reduces future fitness in gulls. J. Avian Biol. 32, 159-166. doi: 10.1034/j.1600-048x.2001.320209.x

Nakasuji, F. (1987). Egg size of skippers (Lepidoptera: Hesperiidae) in relation to their host specificity and to leaf toughness of host plants. Ecol Res. 2, 175-183. doi: $10.1007 / \mathrm{BF} 02346925$

Nathan, R., Schurr, F. M., Spiegel, O., Steinitz, O., Trakhtenbrot, A., and Tsoar, A. (2008). Mechanisms of long-distance seed dispersal. Trends Ecol. Evol. 23, 638-647. doi: 10.1016/j.tree.2008.08.003

Nestor, K. E., Brown, K. I., and Weaver, C. R. (1972). Egg Quality and Poult Production in Turkeys 2. Inheritance and Relationship among Traits. Poultry Sci. 51, 147-158. doi: 10.3382/ps.0510147

Nishizawa, A., Yabuta, Y., and Shigeoka, S. (2008). Galactinol and raffinose constitute a novel function to protect plants from oxidative damage. Plant Physiol. 147, 1251-1263. doi: 10.1104/pp.108.122465

North, H., Baud, S., Debeaujon, I., Dubos, C., Dubreucq, B., Grappin, P., et al. (2010). Arabidopsis seed secrets unravelled after a decade of genetic and omics-driven research. Plant, J. 61, 971-981. doi: 10.1111/j.1365-313X.2009. 04095.x

Nur, N. (1984). The consequences of brood size for breeding blue Tits, I. Adult Survival, Weight Change and the Cost of Reproduction. J. Anim. Ecol. 54, 479-496 doi: 10.2307/4529

Nussbaum, R. A. (1987). Parental care and egg size in salamanders: an examination of the safe harbor hypothesis. Res. Populat. Ecol. 29, 27-44. doi: 10.1007/BF02515423

Nussbaum, R. A., and Schultz, D. L. (1989). Coevolution of parental care and egg size. Am. Natl. 133, 591-603. doi: 10.1086/284939

Obendorf, R. L. (1997). Oligosaccharides and galactosyl cyclitols in seed desiccation tolerance. Seed Sci. Res. 7, 63-74. doi: 10.1017/S096025850000341X

Obeso, J. R. (1993). Seed mass variation in the perennial herb Asphodelus albus: sources of variation and position effect. Oecologia 93, 571-575. doi: $10.1007 /$ BF00328967

Ohto, M., Fischer, R. L., Goldberg, R. B., Nakamura, K., and Harada, J. J. (2005). Control of seed mass by APETALA2. Proc. Natl. Acad. Sci. U.S.A. 102, 3123-3128. doi: 10.1073/pnas.0409858102

Ojanen, M., Orell, M., and Väisänen, R. A. (1979). Role of heredity in egg size variation in the great tit parus major and the pied flycatcher Ficedula hypoleuca. Ornis Scandinavica. Scand. J. Ornithol. 10, 22-28.

Olsen, M. W., and Knox, C. W. (1940). Breeding for egg weight and related characters. Poultry Sci. 19, 254-257. doi: 10.3382/ps.0190254

Orsi, C. H., and Tanksley, S. D. (2009). Natural variation in an ABC transporter gene associated with seed size evolution in tomato species. PLoS Genet. 5:e1000347. doi: 10.1371/journal.pgen.1000347

Parciak, W. (2002). Environmental variation in seed number, size, and dispersal of a fleshy-fruited plant. Ecology 83:780. doi: 10.1890/00129658(2002)083[0780:evisns]2.0.co;2

Parker, G. A., and Begon, M. (1986). Optimal egg size and clutch size: effects of environment and maternal phenotype. Am. Nat. 128, 573-592. doi: $10.1086 / 284589$

Parker, G. A., and Stuart, R. A. (1976). Animal behavior as a strategy optimizer: evolution of resource assessment strategies and optimal emigration thresholds. Am. Nat. 110, 1055-1076. doi: 10.1086/283126

Parsons, J. (1976). Factors determining the number and size of eggs laid by the herring gull. Condor 78, 481-492. doi: 10.2307/1367097
Parsons, P. A. (1964). Egg lengths in Drosophila melanogaster and correlated responses to selection. Genetica 35, 175-181. doi: 10.1007/BF01804886

Paz, H., Mazer, S. J., and Martinez-Ramos, M. (2005). Comparative ecology of seed mass in Psychotria (Rubiaceae): within- and between-species effects of seed mass on early performance. Func. Ecol. 19, 707-718. doi: 10.1111/j.1365-2435.2005.00984.x

Pélabon, C., Albertsen, E., Falahati-Anbaran, M., Wright, J., and Armbruster, W. S. (2015). Does multiple paternity affect seed mass in angiosperms? An experimental test in Dalechampia scandens. J. Evol. Biol. 28, 1719-1733. doi: $10.1111 /$ jeb.12692

Perrin, N. (1988). Why are Offspring Born Larger When It is Colder? Phenotypic Plasticity for Offspring Size in the Cladoceran Simocephalus vetulus (Muller). Func. Ecol. 2, 283-288. doi: 10.2307/2389399

Perrins, C. M. (1965). Population Fluctuations and Clutch-Size in the Great Tit, Parus major L. J. Anim. Ecol. 34, 601-647. doi: 10.2307/2453

Petit, S., Jusaitis, M., and Bickerton, D. (2009). Effect of pollen load, self-pollination and plant size on seeds and germination in the endangered pink-lipped spider orchid, Caladenia behrii. Aust. J. Bot. 57, 307-314. doi: 10.1071/BT08117

Poorter, L., and Rose, S. A. (2005). Light-dependent changes in the relationship between seed mass and seedling traits: a meta-analysis for rain forest tree species. Oecologia 142, 378-387. doi: 10.1007/s00442-004-1732-y

Rees, M. (1996). Evolutionary ecology of seed dormancy and seed size. Phil. Trans. Roy. Soc. Lon. 351, 1299-1308. doi: 10.1098/rstb.1996.0113

Reeve, M. W., Fowler, K., and Partridge, L. (2000). Increased body size confers greater fitness at lower experimental temperature in male Drosophila melanogaster. J. Evol. Biol. 13, 836-844. doi: 10.1046/j.1420-9101.2000. 00216.x

Reich, P. B., Tjoelker, M. G., Walters, M. B., Vanderklein, D. W., and Buschena, C. (1998). Close association of RGR, leaf and root morphology, seed mass and shade tolerance in seedlings of nine boreal tree species grown in high and low light. Funct. Ecol. 12, 327-338. doi: 10.1046/j.1365-2435.1998.00208.x

Reznick, D. (1991). Maternal effects in fish life histories. Unity Evol. Biol. 2, 780-793.

Richdale, L. E. (1963). Biology of the sooty shearwater puffinus griseus. Proc. Zool. Soc. Lon. 141, 1-117. doi: 10.1111/j.1469-7998.1963.tb01603.x

Ricklefs, R. E. (1965). Brood reduction in the Curve-billed Thrasher. Condor 67, 505-510. doi: 10.2307/1365614

Riefler, M., Novak, O., Strnad, M., and Schmülling, T. (2006). Arabidopsis Cytokinin Receptor Mutants Reveal Functions in Shoot Growth, Leaf Senescence, Seed Size, Germination, Root Development, and Cytokinin Metabolism. Plant Cell Online 18, 40-54. doi: 10.1105/tpc.105.037796

Robertson, A. L. (1988). Life histories of some species of Chydoridae (Cladocera: Crustacea). Freshw. Biol. 20, 75-84. doi: 10.1111/j.1365-2427.1988.tb01719.x

Roff, D. A. (1992). Evolution of Life Histories: Theory and Analysis. New York, NY: Chapman \& Hall.

Roff, D. A. (2002). Life History Evolution. Sunderland, MA: Sinauer Associates, Inc. Rollinson, N., and Rowe, L. (2016). The positive correlation between maternal size and offspring size: fitting pieces of a life-history puzzle. Biol. Rev. 91, 1134-1148. doi: $10.1111 /$ brv. 12214

Rüger, N., Wirth, C., Wright, S. J., and Condit, R. (2012). Functional traits explain light and size response of growth rates in tropical tree species. Ecology 93, 2626-2636. doi: 10.1890/12-0622.1

Sadras, V. O. (2007). Evolutionary aspects of the trade-off between seed size and number in crops. Field Crops Res. 100, 125-138. doi: 10.1016/j.fcr.2006.07.004

Saenger, P. (2002). Mangrove Ecology, Silviculture and Conservation. Dordrecht: Springer Science and Business Media.

Salisbury, E. J. (1942). The Reproductive Capacity of Plants: Studies in Quantitative Biology. London: G Bell and Sons Ltd.

Schruff, M. C. (2005). The AUXIN RESPONSE FACTOR 2 gene of Arabidopsis links auxin signalling, cell division, and the size of seeds and other organs. Development 133, 251-261. doi: 10.1242/dev.02194

Schwarzkopf, L., Blows, M. W., and Caley, M. J. (1999). Life-history consequences of divergent selection on egg size in Drosophila melanogaster. Am. Natl. 154, 333-340. doi: $10.2307 / 2463655$

Scott, D. (1962). Effect of food quantity on fecundity of rainbow trout, Salmo gairdneri. J. Fish. Board Can. 19, 715-731. doi: 10.1139/f62-047

Shanbhag, B. A., Radder, R. S., and Saidapur, S. K. (2000). Maternal Size Determines Clutch Mass, Whereas Breeding Timing Influences Clutch and 
Egg Sizes in the Tropical Lizard, Calotes versicolor (Agamidae). Copeia 2000, 1062-1067. doi: 10.1643/0045-8511(2000)000[1062:MSDCMW]2.0.CO;2

Shanbhag, B. A., Saidapur, S. K., and Radder, R. S. (2003). Lowering body temperature induces embryonic diapause during prolonged egg retention in the lizard, Calotes versicolor. Naturwissenschaften 90, 33-35. doi: 10.1007/s00114-002-0382-3

Shi, X. J., Michaels, H. J., and Mitchell, R. J. (2005). Effects of self-pollination and maternal resources on reproduction and offspring performance in the wild lupine, Lupinus perennis (Fabaceae). Sex. Plant Reprod. 18, 55-64. doi: $10.1007 / \mathrm{s} 00497-005-0250-3$

Shine, R. (1978). Propagule size and parental care: the 'safe harbor' hypothesis. J. Theor. Biol. 75, 417-424. doi: 10.1016/0022-5193(78)90353-3

Shine, R. (1989). Alternative models for the evolution of offspring size. Am. Natl. 134, 311-317. doi: $10.1086 / 284982$

Shipley, B., and Dion, J. (1992). The allometry of seed production in herbaceous angiosperms. Am. Natl. 139, 467-483. doi: 10.1086/285339

Shipley, B., and Peters, R. H. (1990). The allometry of seed weight and seedling relative growth rate. Funct. Ecol. 4, 523-529. doi: 10.2307/2389320

Shultz, F. T. (1953). Concurrent inbreeding and selection in the domestic fowl. Heredity 7, 1-21. doi: 10.1038/hdy.1953.1

Simons, A. M. (2011). Modes of response to environmental change and the elusive empirical evidence for bet hedging. Proc. Biol. Sci. R. Soc. B. 278, 1601-1609. doi: $10.1098 /$ rspb. 2011.0176

Simons, A., and Johnston, M. (1997). Developmental instability as a bet-hedging strategy. Oikos 80, 401-406. doi: 10.2307/3546608

Sinervo, B. (1990). The evolution of maternal investment in lizards: an experimental and comparative analysis of egg size and its effects on offspring performance. Evolution 44, 279-294. doi: 10.2307/2409407

Sinervo, B., and Doughty, P. (1996). Interactive effects of offspring size and timing of reproduction on offspring reproduction: experimental, maternal, and quantitative genetic aspects. Res. Gate 50, 1314-1327. doi: 10.2307/2410671

Sinervo, B., and Licht, P. (1991). Proximate constraints on the evolution of egg size, number, and total clutch mass in lizards. Science 252, 1300-1302. doi: $10.1126 /$ science. 252.5010 .1300

Singh, A., Tyagi, A., Tripathi, A. M., Gokhale, S. M., Singh, N., and Roy, S. (2015). Morphological trait variations in the west Himalayan (India) populations of Arabidopsis thaliana along altitudinal gradients. Curr. Sci. 108, 2213-2222.

Slatkin, M. (1974). Competition and regional coexistence. Ecology 55, 128-134. doi: $10.2307 / 1934625$

Smith, C. C., and Fretwell, S. D. (1974). The optimal balance between size and number of offspring. Am. Natl. 108, 499-506. doi: 10.1086/282929

Sogard, S. M. (1997). Size-selective mortality in the juvenile stage of teleost fishes: a review. Bull. Marine Sci. 60, 1129-1157.

Solbreck, C. (1986). Wing and flight muscle polymorphism in a lygaeid bug, Horvathiolus gibbicollis: determinants and life history consequences. Ecol. Entomol. 11, 435-444. doi: 10.1111/j.1365-2311.1986.tb00322.x

Stearns, S. C. (1989). Trade-offs in life-history evolution. Funct. Ecol. 3, 259-268. doi: $10.2307 / 2389364$

Stearns, S. C. (1992). The Evolution of Life Histories. Oxford: University Press Oxford.

Stephens, D. W., Brown, J. S., and Ydenberg, R. C. (2007). Foraging: Behavior and Ecology. Chicago, IL: University of Chicago Press.

Stevenson-Hamilton, J. (2012). South African Eden. Johannesburg: Penguin.

Stewart, L., Hemptinne, J. L., and Dixon, A. (1991). Reproductive tactics of ladybird beetles: relationships between egg size, ovariole number and developmental time. Funct. Ecol. 5, 380-385. doi: 10.2307/2389809

Summers, K., McKeon, C. S., and Heying, H. (2006). The evolution of parental care and egg size: a comparative analysis in frogs. Proc. R. Soc. Lond. Ser. B Biol. Sci. 273, 687-692. doi: 10.1098/rspb.2005.3368

Sun, X., Shantharaj, D., Kang, X., and Ni, M. (2010). Transcriptional and hormonal signaling control of Arabidopsis seed development. Curr. Opin. Plant Biol. 13, 611-620. doi: 10.1016/j.pbi.2010.08.009

Sun, Z., Hamel, J.-F., Parrish, C. C., and Mercier, A. (2015). Complex offspring size effects: variations across life stages and between species. Ecol. Evol. 5, 1117-1129. doi: $10.1002 /$ ece 3.1320

Sundaresan, V. (2005). Control of seed size in plants. Proc. Natl. Acad. Sci. U.S.A. 102, 17887-17888. doi: 10.1073/pnas.0509021102
Temme, D. H. (1986). Seed size variability: a consequence of variable genetic quality among offspring? Evolution 40, 414-417. doi: 10.2307/2408819

Thompson, J. N., and Pellmyr, O. (1989). Origins of variance in seed number and mass: interaction of sex expression and herbivory in Lomatium salmoniflorum. Oecologia 79, 395-402. doi: 10.1007/BF00384320

Thompson, K. (1990). Genome size, seed size and germination temperature in herbaceous angiosperms. Evol. Trends Plants 4, 113-116.

Tielbörger, K., Petruü, M., and Lampei, C. (2012). Bet-hedging germination in annual plants: a sound empirical test of the theoretical foundations. Oikos 121, 1860-1868. doi: 10.1111/j.1600-0706.2011.20236.x

Trivers, R. L. (1974). Parent-offspring conflict. Integr. Comp. Biol. 14, 249-264. doi: $10.1093 / \mathrm{icb} / 14.1 .249$

Turnbull, L. A., Paul-Victor, C., Schmid, B., and Purves, D. W. (2008). Growth rates, seed size, and physiology: do small-seeded species really grow faster. Ecology 89, 1352-1363. doi: 10.1890/07-1531.1

Turnbull, L. A., Philipson, C. D., Purves, D. W., Atkinson, R. L., Cunniff, J., Goodenough, A., et al. (2012). Plant growth rates and seed size: a re-evaluation. Ecology 93, 1283-1289. doi: 10.1890/11-0261.1

Turnbull, L. A., Rees, M., and Crawley, M. J. (1999). Seed mass and the competition/colonization trade-off: a sowing experiment. J. Ecol. 87, 899-912. doi: $10.1046 / j .1365-2745.1999 .00405 . x$

Uma Shaanker, R., and Ganeshaiah, K. N. (1997). Conflict between parent and offspring in plants: predictions, processes and evolutionary consequences. Curr. Sci. 72, 932-939.

Uma Shaanker, R., Ganeshaiah, K. N., and Bawa, K. S. (1988). Parent-offspring conflict, sibling rivalry, and brood size patterns in plants. Ann. Rev. Ecol. Sys. 19, 177-205. doi: 10.1146/annurev.es.19.110188.001141

Uma Shaanker, R., Ganeshaiah, K. N., and Krishnamurthy, K. S. (1995). Development of seeds as self-organizing units: testing the predictions. Int. J. Plant Sci. 156, 650-657. doi: 10.1086/297287

Valen, L. V. (1973). Body size and numbers of plants and animals. Evolution 27, 27-35. doi: $10.2307 / 2407116$

Van Daele, I., Gonzalez, N., Vercauteren, I., de Smet, L., Inzé, D., RoldánRuiz, I., et al. (2012). A comparative study of seed yield parameters in Arabidopsis thaliana mutants and transgenics: a comparative study of seed yield parameters. Plant Biotechnol. J. 10, 488-500. doi: 10.1111/j.1467-7652.2012. 00687.x

Van Den Berghe, E. P., and Gross, M. R. (1989). Natural selection resulting from female breeding competition in a Pacific salmon (coho: Oncorhynchus kisutch). Evolution 43, 125-140. doi: 10.2307/2409169

van der Pijl, L. (1969). Principles of Dispersal in Higher Plants. Heidelberg: Springer-Verlag.

Vander Werf, E. (1992). Lack's clutch size hypothesis: an examination of the evidence using meta-analysis. Ecology 73, 1699-1705 doi: 10.2307/1940021

Vaughton, G., and Carthew, S. M. (1993). Evidence for selective fruit abortion in Banksia spinulosa (Proteaceae). Biol. J. Linn. Soc. 50, 35-46 doi: 10.1111/j.1095-8312.1993.tb00917.x

Venable, D. L. (1992). Size-number trade-offs and the variation of seed size with plant resource status. Am. Nat. 140, 287-304. doi: 10.1086/285413

Venable, D. L., and Brown, J. S. (1988). The selective interactions of dispersal, dormancy, and seed size as adaptations for reducing risk in variable environments. Am. Nat. 131, 360-384. doi: 10.1086/284795

Venable, D. L., and Rees, M. (2009). The scaling of seed size. J. Ecol. 97, 27-31. doi: $10.1111 / j .1365-2745.2008 .01461 . x$

Visser, M. E., and Lessells, C. M. (2001). The costs of egg production and incubation in great tits (Parus major). Proc. R. Soc. Lond. B 268, 1271-1277. doi: 10.1098/rspb.2001.1661

Volis, S., Mendlinger, S., and Ward, D. (2002). Differentiation in populations of Hordeum spontaneum along a gradient of environmental productivity and predictability: life history and local adaptation. Biol. J. Linn. Soc. 77, 479-490. doi: 10.1046/j.1095-8312.2002.00120.x

Wallace, A. R. (1878). Tropical Nature, and Other Essays. London: Macmillan and Company.

Wang, A., Garcia, D., Zhang, H., Feng, K., Chaudhury, A., Berger, F., et al. (2010). The VQ motif protein IKU1 regulates endosperm growth and seed size in Arabidopsis: IKU1, a VQ motif protein, regulates seed size. Plant, J. 63, 670-679. doi: 10.1111/j.1365-313X.2010.04271.x 
Wang, D. Y. C., Kumar, S., and Hedges, S. B. (1999). Divergence time estimates for the early history of animal phyla and the origin of plants, animals and fungi. Proc. R. Soc. Lond. B Biol. Sci. 266, 163-171. doi: 10.1098/rspb. 1999.0617

Warren, D. C. (1924). Inheritance of egg size in Drosophila melanogaster. Genetics 9, 41-69.

Westoby, M., Falster, D. S., Moles, A. T., Vesk, P. A., and Wright, I. J. (2002). Plant ecological strategies: some leading dimensions of variation between species. Annu. Rev. Ecol. Syst. 33, 125-159. doi: 10.1146/annurev.ecolsys.33.010802.150452

Westoby, M., Jurado, E., and Leishman, M. (1992). Comparative evolutionary ecology of seed size. Trends Ecol. Evol. 7, 368-372. doi: 10.1016/01695347(92)90006-W

Wiklund, C., and Karlsson, B. (1984). Egg size variation in satyrid butterflies: adaptive vs historical,'Bauplan', and mechanistic explanations. Oikos 43, 391-400. doi: 10.2307/3544158

Wiklund, C., and Persson, A. (1983). Fecundity, and the relation of egg weight variation to offspring fitness in the speckled wood butterfly Pararge aegeria, or why don't butterfly females lay more eggs? Oikos 40, 53-63. doi: $10.2307 / 3544198$

Wiklund, C., Karlsson, B., and Forsberg, J. (1987). Adaptive versus constraint explanations for egg-to-body size relationships in two butterfly families. Am. Nat. 130, 828-838. doi: 10.1086/284750

Wilson, K., and Lessells, C. (1994). Evolution of clutch size in insects.I. A review of static optimality models. J. Evol. Biol. 7, 339-363. doi: 10.1046/j.1420-9101.1994.7030339.x

Wingard, S. A. (1927). The immediate effect of cross-pollination on the size and shape of bean seed. Genetics 12, 115-124.

Winkler, D. W., and Walters, J. R. (1983). "The determination of clutch size in precocial birds," in Current Ornithology, ed R. F. Johnston (New York, NY: Springer), 33-68.
Wulff, R. D. (1986). Seed size variation in Desmodium paniculatum: I. Factors affecting seed size. J. Ecol. 74, 87-97. doi: 10.2307/2260350

Yampolsky, L. Y., and Scheiner, S. M. (1996). Why larger offspring at lower temperatures? A demographic approach. Am. Nat. 147, 86-100. doi: $10.1086 / 285841$

Yanagi, S. I., and Miyatake, T. (2002). Effects of maternal age on reproductive traits and fitness components of the offspring in the bruchid beetle, Callosobruchus chinensis (Coleoptera: Bruchidae). Physiol. Entomol. 27, 261-266. doi: 10.1046/j.1365-3032.2002.00294.x

Yoine, M. (2006). Arabidopsis UPF1 RNA Helicase for Nonsense-mediated mRNA Decay is Involved in Seed Size Control and is Essential for Growth. Plant Cell Physiol. 47, 572-580. doi: 10.1093/pcp/pcj035

Zhang, L. C., Ning, Z. H., Xu, G. Y., Hou, Z. C., and Yang, N. (2005). Heritabilities and genetic and phenotypic correlations of egg quality traits in brown-egg dwarf layers. Poult. Sci. 84, 1209-1213. doi: 10.1093/ps/84. 8.1209

Zhou, Y., Zhang, X., Kang, X., Zhao, X., Zhang, X., and Ni, M. (2009). SHORT HYPOCOTYL UNDER BLUE1 associates with MINISEED3 and HAIKU2 promoters in vivo to regulate Arabidopsis seed development. Plant Cell Online 21, 106-117. doi: 10.1105/tpc.108.064972

Conflict of Interest Statement: The authors declare that the research was conducted in the absence of any commercial or financial relationships that could be construed as a potential conflict of interest.

Copyright (C) 2017 Dani and Kodandaramaiah. This is an open-access article distributed under the terms of the Creative Commons Attribution License (CC BY). The use, distribution or reproduction in other forums is permitted, provided the original author(s) or licensor are credited and that the original publication in this journal is cited, in accordance with accepted academic practice. No use, distribution or reproduction is permitted which does not comply with these terms. 